\title{
EVALUASI PENGELOLAAN DANA KAS PADA DEPARTEMEN KONSERVASI SUMBERDAYA HUTAN DAN EKOWISATA IPB
}

\author{
SITI BUNGA UTAMI \\ DIAH WAHYUNINGSIH
}

\begin{abstract}
ABSTRAK
Kas adalah aset perusahaan yang paling likuid dan juga merupakan sumberdaya yang mutlak diperlukan untuk menjalankan kegiatan operasional perusahaan. Keberadaan kas sangat mudah dipindahtangankan sehingga beresiko tinggi dari tindakan penyelewengan dan penyalahgunaan. Oleh karena itu, diperlukan adanya pengelolaan yang baik dan transparan agar tidak memberikan pengaruh yang buruk terhadap perusahaan dan mengganggu kelancaran kegiatan operasionalnya.

Tujuan peninjauan ini adalah untuk mengevaluasi pengelolaan dana kas kecil pada sebuah lembaga pendidikan dalam melakukan kegiatan operasionalnya dengan cara mengetahui bagaimana sistem dan posedur pembentukan, pencatatan, penggunaan dan pengisian dana kas serta sistem pengendalian dan pengawasan dana kasnya. Evaluasi dilakukan untuk mengetahui apakah pengelolaan dana kas yang dilakukan pada lembaga pendidikan tersebut sudah berjalan secara baik berdasarkan sistem dan prosedur yang diterapkan. Peninjauan yang dilakukan penyusun adalah di Departemen Konservasi Sumberdaya Hutan dan Ekowisata (DKSHE) IPB, yang berlokasi di Dramaga Bogor. DKSHE merupakan lembaga pendidikan yang menyelenggarakan dan mengembangkan pendidikan akademik pada Program Sarjana dan Pasacasarjana.

Hasil peninjauan menunjukkan bahwa sistem dan prosedur pembentukan dana kas kecil DKSHE mengikuti aturan dan ketentuan yang berlaku di IPB, pencatatan yang dilakukan Bendahara Pengeluaran Pembantu (BPP) hanya berupa Kas Tunai Manual dan mengisi Sistem Informasi Keuangan (SIMKEU) IPB, masih terdapat kelemahan dari segi arus dokumen dalam penggunaan dana kasnya, pengisian kembali dana kas dilakukan ketika sudah mencapai batas minimum dengan mengikuti sistem dan prosedur yang berlaku di IPB, terdapat adanya otorisasi pihak yang berwenang pada pengendalian dan pengawasan dana kasnya, dan tidak adanya fungsi pemisahan tugas dan tanggung jawab bagian yang mengelola dana kas DKSHE.
\end{abstract}

Keywords : evaluasi, pembentukan, pengendalian, pengelolaan 


\section{BAB I}

\section{PENDAHULUAN}

\subsection{Latar Belakang}

Setiap tata usaha keuangan pada suatu lembaga, instansi atau perusahaan melakukan transaksi kas. Kas merupakan aset perusahaan yang paling likuid. Wujud kas terdiri dari uang logam, uang kertas, cek, giro, wesel, dan simpanan uang yang tersedia untuk ditarik kapan saja dari bank dan lembaga keuangan lainnya. Keberadaan kas sangat mudah dipindahtangankan dan kepemilikannya tidak dapat dibuktikan, sehingga kas sangat beresiko tinggi dari terjadinya penyelewengan dan penyalahgunaan. Penyelewengan dan penyalahgunaan terhadap kas contohnya yaitu terjadinya ketidaksesuaian pencatatan penerimaan kas dari saldo yang seharusnya, pelaporan beban yang berlebihan untuk ongkos perjalanan agar mendapat penggantian yang lebih besar dari perusahaan, penggunaan dana sementara waktu oleh karyawan untuk kepentingan pribadi tanpa melakukan pencatatan, mencatat pengeluaran palsu tanpa ada transaksi yang sebenarnya, menyiapkan bukti voucher palsu atau pengajuan voucher pembayaran sebanyak dua kali, pemindahan dana dari bank perusahaan ke bank milik karyawan dan lain sebagainya. Dengan demikian, tindakan pengamanan dan pengawasan terhadap kas sangat diperlukan.

Kas memiliki peranan penting bagi suatu perusahaan, karena kas merupakan sumber daya yang mutlak diperlukan untuk menjalankan kegiatan operasionalnya. Biasanya penggunaan kas terjadi pada setiap hari kerja, sejak awal jam operasional sampai dengan akhir jam operasional. Tanpa adanya kas, aktivitas pada suatu perusahaan tidak akan berjalan dengan baik sehingga perusahaan pun harus mengelola kas dengan baik. Apabila perusahaan kurang baik dalam mengelola kas maka dapat mengganggu kelancaran kegiatan operasionalnya bahkan dapat memberikan pengaruh yang buruk terhadap perusahaan.

Begitu pun halnya dengan Departemen Konservasi Sumberdaya Hutan dan Ekowisata (DKSHE) IPB. Dalam kegiatan rutinitasnya, DKSHE membentuk dana kas yang bertujuan untuk membiayai kegiatan operasionalnya. Biasanya dana kas tersebut digunakan untuk membiayai pengeluaran yang secara 
terencana maupun yang tidak terencana, seperti pembelian materai, alat tulis kantor, jamuan rapat, biaya praktikum mahasiswa, honorarium dosen atau tenaga ahli dari luar IPB dan lain sebagainya. Dana kas yang dimiliki oleh DKSHE tidak hanya tersedia di tangan tetapi juga tersedia di bank dengan jumlah yang relatif besar, sehingga DKSHE harus mengelola dana kas yang dimiliki dengan baik dan secara transparan. Dengan diterapkannya pengelolaan dana kas yang baik dan secara transparan dapat meminimalisir terjadinya penyalahgunaan ataupun penyelewengan dalam penggunaan dana oleh pihak tertentu yang dapat menghambat kelancaran aktivitas bahkan dapat mengakibatkan kerugian.

Berdasarkan uraian latar belakang penyusunan tugas akhir di atas, maka penyusun mengambil judul "Evaluasi Pengelolaan Dana Kas pada Departemen Konservasi Sumberdaya Hutan dan Ekowisata IPB".

\subsection{Identifikasi Masalah}

Berdasarkan latar belakang penyusunan tugas akhir di atas, maka penyusun mengidentifikasikan permasalahan yang akan dibahas sebagai berikut:

1. Bagaimana prosedur pembentukan, pencatatan, penggunaan dan pengajuan dana kas pada Departemen Konservasi Sumberdaya Hutan dan Ekowisata IPB ?

2. Bagaimana pengendalian dan pengawasan dana kas pada Departemen Konservasi Sumberdaya Hutan dan Ekowisata IPB?

3. Apakah pengelolaan dana kas pada Departemen Konservasi Sumberdaya Hutan dan Ekowisata IPB sudah berjalan dengan baik?

\subsection{Maksud dan Tujuan}

Maksud dan tujuan dari pelaksanaan penyusunan tugas akhir adalah sebagai berikut:

1. Untuk mengetahui prosedur pembentukan, pencatatan, penggunaan, dan pengajuan dana kas pada Departemen Konservasi Sumberdaya Hutan dan Ekowisata IPB 
2. Untuk mengetahui kelemahan dan kelebihan sistem pengendalian serta pengawasannya dalam mengelola dana kas yang ada pada Departemen Konservasi Sumberdaya Hutan dan Ekowisata IPB

3. Mengevaluasi pengelolaan dana kas pada Departemen Konservasi Sumberdaya Hutan dan Ekowisata IPB

\subsection{Kegunaan Penyusunan Tugas Akhir}

Kegunaan penyusunan tugas akhir ini adalah sebagai berikut :

1. Bagi Penyusun

Diharapkan dapat memberikan wawasan dan pengalaman baru mengenai pengelolaan dana kas dari dunia kerja yang sebenarnya, selain dari ilmu teori yang diterima selama masa perkuliahan.

2. Bagi Lembaga Terkait

Diharapkan dapat memberikan saran perbaikan sehingga dapat dijadikan sebagai dasar pertimbangan dalam pengelolaan dana kas agar lebih efektif.

3. Bagi Akademik

Selain sebagai syarat kelulusan, hasil tugas akhir ini dapat digunakan oleh mahasiswa STIE Kesatuan sebagai wawasan, pengetahuan, referensi dan dijadikan informasi tambahan mengenai sistem pengelolaan dana kas yang baik. 



\section{BAB II \\ TINJAUAN PUSTAKA}

\subsection{Sistem dan Prosedur}

Dalam melakukan fungsi operasional, perusahaan pada umumnya menggunakan sistem dan prosedur kerja. Penerapan sistem dan prosedur yang baik berguna untuk kelancaran operasional perusahaan dalam upaya mencapai tujuan perusahaan.

\subsubsection{Pengertian Sistem}

Pengertian sistem yang dikemukakan oleh Adikesavan (2014, 330), yaitu "a group of interrelated components working together toward a common goal by accepting inputs and producing outputs in a organized transformation process". Argumen tersebut sejalan dengan pendapat Hall $(2007,6)$ yaitu "sistem adalah kelompok dari dua atau lebih komponen atau subsistem yang saling berhubungan yang berfungsi dengan tujuan yang sama". Dari kedua pendapat tersebut, didukung oleh pendapat Al Fatta (2007, 3) yang menyatakan bahwa "sistem adalah suatu kumpulan atau himpunan dari unsur atau variabel-variabel yang saling terorganisasi, saling berinteraksi dan saling bergantung satu sama lain". Begitu pun halnya dengan pendapat Hutahaean (2014, 2) yang menjabarkan bahwa "sistem adalah jaringan kerja dari prosedur-prosedur yang saling berhubungan, berkumpul bersama-sama untuk melakukan kegiatan atau untuk melakukan sasaran yang tertentu".

Sistem dapat dikelompokkan menjadi dua pendekatan. Pendekatan yang pertama, sistem lebih menekankan pada elemen-elemen atau kelompoknya. Dalam hal ini, sistem merupakan suatu jaringan kerja dari prosedur-prosedur yang saling berhubungan, berkumpul bersama-sama untuk melakukan suatu kegiatan atau menyelesaikan suatu aturan tertentu. Kemudian pendekatan yang kedua, sistem merupakan jaringan kerja dari prosedur dimana pada pendekatan ini lebih menekankan kepada urutan operasinya di dalam sistem (Kusrini dan Koniyo, 2007). 
Berdasarkan uraian tersebut di atas, maka sistem dapat diartikan sebagai suatu jaringan kerja yang terdiri dari dua atau lebih komponen yang saling berhubungan satu sama lain dalam menyelesaikan suatu aturan tertentu untuk mencapai suatu tujuan perusahaan.

\subsubsection{Pengertian Prosedur}

Prosedur yang dikemukakan oleh Zulkifli Amsyah (2005, 33) yaitu "aturan bermain, aturan bekerjasama, aturan berkoordinasi, sehingga unitunit dalam sistem, subsistem, subsubsistem, dan seterusnya dapat berinteraksi satu sama lain secara efektif dan efisien", sedangkan menurut Richard F. Neushl dalam Kusrini dan Koniyo $(2007,5)$ prosedur diartikan sebagai "urutan operasi kerja (tulis-menulis), yang biasanya melibatkan beberapa orang di dalam satu atau lebih departemen, dan diterapkan untuk menjamin penanganan yang seragam dari transaksi bisnis yang terjadi".

Selain pendapat tersebut di atas, pengertian lainnya dari prosedur adalah "a document written to support a Policy Directive and designed to describe Who, What, Where, When, and Why by means of establishing corporate accountability in support of the implementation of a policy" (en.wikipedia.org/wiki/Procedure). Prosedur yang dirancang tersebut terdiri dari urutan klerikal yang didalamnya melibatkan beberapa orang atau bagian yang saling terkait dengan tujuan untuk menangani transaksi secara seragam dan terjadi berulang-ulang" (Arifin dan Sumaryono, 2007, 20).

Ida Nuraida $(2008,36)$ menjabarkan bahwa prosedur adalah pedoman untuk bertindak yang berisi metode-metode yang dibutuhkan atau urutanurutan dalam menangani aktivitas-aktivitas yang akan datang dan mencapai tujuan tertentu. Biasanya prosedur yang ada pada suatu perusahaan berupa prosedur tertulis, dimana isi dalam prosedur tersebut bersifat formal dan diakui oleh semua orang dalam suatu organisasi. Prosedur hendaknya selalu diperbaharui agar perkembangan suatu organisasi dapat berjalan secara aktif dan dinamis.

Berdasarkan uraian tersebut di atas, maka dapat ditarik kesimpulan bahwa prosedur merupakan suatu aturan yang terdiri dari urutan-urutan kerja dan dirancang oleh perusahaan untuk menangani transaksi bisnis secara seragam yang terjadi secara berulang-ulang, dimana dalam sebuah prosedur 
melibatkan beberapa orang atau bagian di dalamnya dan untuk mencapai tujuan suatu perusahan.

\subsection{Pengertian Sistem Informasi Akuntansi}

Menurut Kusrini dan Koniyo $(2007,10)$ sistem informasi akuntansi yaitu "suatu sistem yang mengubah data transaksi bisnis menjadi informasi keuangan sehingga dapat berguna bagi pemakainya", seperti halnya dengan pendapat Kieso et al. $(2011,80)$ yang menyatakan bahwa "an accounting information system collect and process transaction data and then disseminates the financial information to interested parties".

Pengertian lain yang dikemukakan oleh Jones dan Rama $(2008,6)$, sistem informasi akuntansi yaitu "subsistem dari informasi manajemen yang menyediakan informasi keuangan dan akuntansi, serta dapat memberikan informasi dari pemrosesan transaksi akuntansi secara rutin". Begitu pula dengan pendapat Samiaji $(2009,13)$ yang mengemukakan bahwa sistem informasi akuntansi merupakan "sistem yang mengumpulkan, mencatat, menyimpan dan memproses data sehingga menghasilkan informasi yang berguna dalam membuat keputusan".

Selain itu, Indra Bastian (2006, 208) menjabarkan bahwa sistem informasi akuntansi adalah mekanisme dari komponen atau sumberdaya yang terdiri dari identifikasi, analisis, pengukuran, pencatatan, peringkasan serta pengomunikasian untuk menghasilkan sebuah informasi data keuangan dan bertanggungjawab melaporkan hasil-hasil operasi perusahaan kepada pihakpihak yang berkepentingan.

Sumberdaya pada sistem informasi akuntansi terdiri dari prosessor, database, instrument input atau output, dan sumberdaya lainnya. Adapun uraian dari keempat sumberdaya sistem informasi akuntansi tersebut, yaitu sebagai berikut:

1. Prosessor

Instrumen fisik yang digunakan untuk mentransformasi data menjadi informasi.

2. Database

Database merupakan semua data yang disimpan. Dalam arti luas, database merupakan data yang disimpan pada sistem komputer maupun dalam lemari-lemari arsip, sedangkan dalam arti sempit 
database biasanya yaitu data yang disimpan dan terorganisasi pada sistem komputer.

3. Instrument input atau output

Instrument input dan output adalah instrumen fisik yang menangani pemasukan, penyimpanan, dan penyajian data serta informasi.

4. Sumberdaya lainnya

Sumber daya lainnya meliputi karyawan yang mengoperasikan sistem, aktiva tetap yang menjadi sarana dan prasarana sistem, serta dana untuk pemeliharaan dan pengembangan sistem.

Berdasarkan uraian tersebut di atas, maka dapat ditarik kesimpulan bahwa sistem informasi akuntansi merupakan serangkaian aktivitas yang terdiri dari beberapa komponen atau sumber daya, dimana di dalamnya terdapat sebuah proses pengumpulan, pencatatan, penyimpanan serta pemrosesan data, sehingga dapat menghasilkan data berupa informasi keuangan yang dapat berguna bagi perusahaan dalam pengambilan keputusan.

\subsection{Kas}

\subsubsection{Pengertian Kas}

Menurut Kieso et al. (2011, 344), "Cash the most liquid of assets, is the standard medium of exchange and the basis for measuring and accounting for all other items". Argumen tersebut pun didukung oleh pendapat SEQUOIA Content Production dan Leviandi Adhie $(2010,86)$, yang menyatakan bahwa kas merupakan "alat pembayaran yang sifatnya liquid, siap dan cepat untuk digunakan perusahaan dalam membiayai kegiatan umum perusahaan".

Dalam PSAK No. 2 Paragraf 5 (IAI:2012) menjabarkan bahwa kas terdiri atas saldo kas (cash on hand) dan saldo rekening giro. Setara Kas merupakan investasi yang bersifat likuid berjangka pendek dan dengan cepat dijadikan kas dalam jumlah tertentu tanpa menghadapi resiko perubahan nilai yang signifikan. Argumen tersebut pun didukung oleh pendapat Warren (2014, 407) yang menyatakan bahwa "kas terdiri uang logam, uang kertas, cek, giro, wesel, dan simpanan uang yang tersedia untuk ditarik kapan saja dari bank dan lembaga keuangan lainnya". 
Kas dijadikan sebagai alat pertukaran oleh perusahaan yang siap digunakan kapanpun untuk melakukan transaksi (Rudianto, 2012, 188). Kas biasanya digunakan perusahaan untuk membiayai kegiatan operasional perusahaan, membayar kewajiban perusahaan, atau melakukan investasi guna mencapai tujuan suatu perusahaan tersebut. Selain itu, kas adalah aset perusahaan yang paling likuid keberadaannya jika dibandingkan dengan aset perusahaan lainnya. Namun, kepemilikan atas kas tersebut tidak bisa dibuktikan.

Berdasarkan uraian tersebut di atas, maka dapat disimpulkan bahwa kas merupakan aset penting yang dimiliki oleh perusahaan untuk digunakan sebagai alat transaksi, dalam membiayai kegiatan operasional, membayar kewajiban serta berinvestasi.

\subsubsection{Pengelolaan Kas Perusahaan}

Alfian Malik (2010, 224) menjabarkan bahwa kas yang dimiliki oleh perusahaan harus dikelola dengan baik. Kebanyakan, para pelaku bisnis lebih berorientasi dan terfokus kepada laba usaha dan mengabaikan pengelolaan kasnya karena menganggap pengelolaan kas merupakan fungsi opsional. Banyak perusahaan yang mendapat keuntungan dari bisnisnya namun tidak memiliki kas yang cukup untuk membayar gaji karyawan, padahal perusahaan tersebut memiliki aset yang relatif besar. Hal tersebut disebabkan karena manajemen kas yang tidak benar.

Abubakar dan Wibowo $(2004,18)$ juga menjabarkan bahwa pengelolaan kas pada suatu perusahaan sangat diperlukan agar kegiatan operasionalnya dapat berjalan dengan baik dan pembayaran-pembayaran utang yang jatuh tempo dapat dilakukan. Efektifitas pengelolaan kas memerlukan pengendalian dan proteksi terhadap kas sehingga dapat dihindari kerugian akibat terjadinya pencurian dan penggunaan yang salah. Perusahaan harus merencanakan semua yang berhubungan dengan masuk keluarnya kas serta melihat kesulitan-kesulitan yang dihadapi.

Selain itu, perusahaan juga harus mengestimasi jumlah uang dan kapan uang tersebut akan masuk, sebaliknya juga perusahaan harus mengestimasi jumlah uang dan kapan harus dikeluarkan. Dengan demikian, jika diketahui terdapat kekurangan kas maka akan dilakukan usaha-usaha untuk menutupi 
kekurangan tersebut dan sebaliknya jika terdapat kelebihan kas, maka perusahaan dapat merencanakan penggunaannya secara efektif.

Agar kebutuhan kas dapat diketahui dari waktu ke waktu maka perlu disusun anggaran arus kas dengan mempertimbangkan berbagai faktor secara makro, misalnya kondisi perekonomian, moneter, dan sosial politik. Pada prinsipnya anggaran kas meliputi adanya rencana penerimaan dan pengeluaran. Oleh karena itu anggaran kas selalu terkait dengan aktivitas perusahaan, misalnya aktivitas penjualan dan pemasaran, produksi, pembayaran gaji, dan upah karyawan. Perlu diketahui bahwa saldo kas yang terdapat anggaran kas bukanlah laba perusahaan. Bentuk susunan anggaran kas dapat berupa kolom-kolom yang berisi mengenai estimasi kas masuk dan keluar pada masa yang akan datang. Biasanya periode anggaran kas disusun setiap bulan, tiga bulan atau enam bulan. Dengan adanya anggaran kas manajemen, perusahaan dapat memperkirakan jumlah uang tunai yang dibutuhkan.

Kunci utama dalam pengelolaan kas perusahaan yaitu melakukan pencatatan serta administrasi yang rapi dan teratur. Setiap satu rupiah yang masuk dan keluar harus dicatat dengan secermat mungkin dan disertai dengan adanya bukti transaksi yang memadai. Beberapa hal yang perlu diperhatikan dalam mengelola kas perusahaan yaitu sebagai berikut:

1. Buat catatan yang teratur dan rapi beserta dokumen atau bukti transaksi yang lengkap atas seluruh uang yang masuk dan keluar serta dijelaskan mengenai tujuan penggunaannya

2. Teliti terhadap dokumen atau bukti transaksi dan pastikan bahwa bukti tersebut absah dan tidak fiktif

3. Pisahkan catatan mengenai asset pribadi dan asset perusahaan, sehingga memudahkan untuk mengelolanya

4. Jika perlu gunakan jasa perbankan untuk beberapa transaksi dianggap besar dan jika perlu membuka rekening khusus untuk tujuan pengendalian kas

5. Susunlah anggaran untuk periode tertentu dari berbagai rencana bisnis yang terjadi dalam pelaksanaan anggaran penjualan, anggaran produksi, anggaran kas, dan sebagainya

6. Lakukan analisis secara sederhana jika terjadi penyimpanganpenyimpangan yang terjadi dalam pelaksanaan anggaran dan cari penyebab-penyebab terjadinya penyimpangan tersebut 
7. Hal penting lain adalah menciptakan pengendalian internal dengan cara pemisahan antara fungsi pencatatan, penyimpanan dab pembayaran

8. Lakukan verifikasi secara periodik untuk menyakinkan bahwa pengendalian internal berjalan secara efektif

9. Susunlah laporan rekonsiliasi bank setiap akhir bulan jika perusahaan mempunyai rekening di bank yang merupakan partner perusahaan

10. Bentuklah dana kas kecil untuk membiayai pengeluaran yang jumlahnya relatif dan terjadi berulang-ulang

11. Bentuk pengamanan kas secara fisik atas sejumlah uang tunai yang ada di perusahaan

Perusahaan harus merencanakan semua yang berhubungan dengan masuk keluarnya kas serta melihat kesulitan yang dihadapi perusahaan. Selain itu, perusahaan pun harus mengestimasi jumlah uang dan kapan uang tesebut akan masuk atau keluar. Dengan demikian, jika diketahui terdapat adanya kekurangan kas maka perusahaan melakukan usaha untuk menutupinya. Begitu pula sebaliknya, apabila terdapat kelebihan kas, maka perusahaan dapat merencanakan penggunaannya secara efektif.

Untuk mengetahui kebutuhan kas dari waktu ke waktu, maka perusahaan perlu menyusun anggaran kas (cash flow budget) dengan mempertimbangkan berbagai faktor secara makro, seperti kondisi perekonomian, moneter, dan social politik. Pada prinsipnya anggaran kas meliputi rencana penerimaan dan pengeluaran, sehingga anggaran kas selalu terkait dengan aktivitas-aktivitas perusahaan, seperti aktivitas penjualan dan pemasaran, produksi, pembayaran gaji, dan upah karyawan. Dengan adanya anggaran kas, perusahaan dapat memperkirakan apakah perusahaan perlu menambah uang tunai yang dibutuhkan, jumlah yang dibututkan, kapan harus dilakukan, dan bagaimana cara memperoleh uang tunai tersebut.

\subsubsection{Pengertian Sistem Pengendalian Internal Kas}

Keberadaan suatu kas pada perusahaan sangat rentan untuk dipindahtangankan dan berpotensial dari kecurangan, sehingga sangat diperlukan adanya suatu sistem pengendalian internal kas. Sugiono et al. (2010, 149) menilai bahwa sistem pengendalian internal kas merupakan 
metode serta kebijaksanaan yang terkoordinasi dalam suatu perusahaan untuk mengamankan harta kekayaannya, menguji ketepatan dan sampai seberapa jauh data akuntansi dapat dipercaya dan meningkatkan efisiensi. Argumen tersebut pun sejalan dengan pendapat Sodikin $(2013,5)$ yang menyatakan bahwa sistem pengendalian internal kas adalah bentuk pengawasan terhadap kas yang bertujuan untuk melindungi kas agar tidak terjadi adanya penyalahgunaan terhadap kas. Sistem pengendalian internal kas dapat dilakukan dengan pemeriksaan rutin terhadap keakuratan transaksi tunai yang dicatat dan adanya pemisahan tugas karyawan, seperti halnya yang dikemukakan oleh Wahlen et al. $(2013,65)$, yaitu "Cash control systems is enhanced by routine reviews of the accuracy of recorded cash transactions and the separation of employee duties".

Keberadaan kas pada suatu perusahaan sangat berpotensial dari kecurangan ataupun penyalahgunaan, karena pihak yang terlibat langsung adalah karyawan perusahaan. Oleh karena itu, perusahaan perlu menerapkan adanya sistem pengendalian detektif. Sistem pengendalian detektif merupakan prosedur-prosedur yang dirancang untuk mendeteksi terjadinya pencurian ataupun penyalahgunaan kas oleh karyawan, sehingga apabila karyawan tetap melakukan kecurangan ataupun penyalahgunaan kas, maka kemungkinan besar hal tersebut akan terungkap. Selain itu, perusahaan juga harus menerapkan sistem pengendalian preventif dimana pada sistem ini terdiri dari prosedur-prosedur yang digunakan mulai dari kas diterima sampai dengan kas disetorkan ke bank untuk melindungi kas dari pencurian ataupun penyalahgunaan (Warren et. al, 2008, 321).

Berdasarkan uraian tersebut di atas, maka dapat disimpulkan bahwa sistem pengendalian internal kas merupakan suatu langkah penting yang harus diterapkan dan dijalankan oleh perusahaan terhadap kas yang dimiliki. Dengan adanya penerapan sistem pengendalian internal tersebut, dapat melindungi kas dari pencurian ataupun penyalahgunaan yang dilakukan oleh karyawan.

\subsubsection{Pengendalian Kas Terhadap Penerimaan dan Pembayaran}

Pengendalian kas yang dijabarkan oleh Warren et al. $(2014,407)$ yaitu pengendalian kas terhadap penerimaan kas dan pengendalian terhadap penerimaan kas. Pengendalian kas terhadap penerimaan kas dilakukan untuk 
melindungi kas dari pencurian dan penyalahgunaan, sehingga perusahaan harus mengendalikan kas sejak kas tersebut diterima sampai dengan kas disimpan di bank.

Biasanya perusahaan mendapatkan kas dari dua sumber yaitu berasal dari pelanggan yang membeli barang atau jasa dan pelanggan yang membayar piutangnya, misalnya kas yang diterima dari penjualan tunai, kas yang diterima melalui cek atau giro, dan kas yang diterima melalui transfer dana elektronik.

1. Kas yang diterima dari penjualan tunai

Dalam penjualan tunai, pengendalian yang penting untuk melindungi kas yang diterima yaitu dengan mesin kasir. Mesin kasir berguna untuk mengendalikan kas sebagai berikut:

a. Pada awal masa giliran kerja, kasir diberi uang kas yang telah ditentukan jumlahnya yang dijadikan sebagai saldo awal dan disimpan dalam laci. Saldo awal tersebut dijadikan sebagai uang kembalian untuk pelanggan yang melakukan pembelian tunai.

b. Ketika kasir memasukkan angka penjualan, biasanya pada layar monitor yang menghadap ke sisi pelanggan akan menunjukkan jumlah transaksi. Hal ini memungkinkan pelanggan untuk memverifikasi bahwa kasir telah menagih dengan jumlah yang benar.

c. Pada akhir masa giliran kerja, kasir dan pengawasnya menghitung kas dalam laci kasir. Jumlah kas harus sesuai dengan jumlah kas saldo awal dengan ditambah jumlah penjualan tunai pada hari tersebut.

d. Pengawas membawa kas ke departemen kasir dan ditempatkan di tempat yang aman.

e. Pengawas menyampaikan salinan struk-struk mesin kasir ke departemen akuntansi.

f. Petugas bagian akuntansi menyiapkan bukti setoran bank.

g. Kasir menyetorkan uang ke bank atau uang diantar oleh jasa mobil pengamanan berlapis baja.

h. Departemen akuntansi merangkum penerimaan kas dan mencatat penjualan tunai hari itu.

i. Ketika kas disetor ke bank, bank akan membubuhkan validasi pada salinan lembaran setoran bank. Bukti setoran bank ini dikembalikan ke departemen akuntansi yang akan dibandingkan 
dengan jumlah yang seharusnya disetor. Pengendalian ini membantu untuk memastikan bahwa semua uang yang disimpan dan tidak ada uang tunai yang hilang atau dicuri saat perjalanan ke bank. Apabila terdapat kekurangan yang terjadi maka akan segera terdeteksi.

2. Kas yang diterima melalui cek atau giro

Kas yang diterima berasal dari pelanggan yang membayar tagihan dalam bentuk cek atau giro. Kebanyakan faktur perusahaan dirancang agar para pelanggan mengembalikan potongan faktur yang berisi jumlah tagihan yang disebut slip pembayaran. Slip pembayaran dapat digunakan untuk mengendalikan kas yang diterima melalui cek atau giro sebagai berikut:

a. Karyawan yang menerima cek dan slip pembayaran tersebut pertama-tama harus membandingkan angka yang tercantum pada cek yang diterima dengan jumlah terutang di slip pembayaran.

b. Karyawan membubuhkan stempel cek dan giro dengan "Hanya untuk setoran" dalam rekening bank perusahaan.

c. Slip pembayaran dan total rangkumannya dikirim ke Departemen Akuntansi.

d. Seluruh cek dan giro yang diterima kemudian diserahkan ke Departemen Kasir.

e. Petugas akan menyiapkan lembar setoran bank.

f. Petugas menyetorkan kas ke bank atau uang diantar oleh jasa mobil pengamanan berlapis baja.

g. Staf akuntansi akan mencatat transaksi dan memindahbukukan pembayaran sebagai pengurang saldo piutang kea kun pelanggan terkait.

h. Saat kas disetorkan ke bank, biasanya bank akan membubuhkan validasi pada salinan lembar setoran bank. Slip setoran yang telah di validasi ini dikembalikan ke departemen akuntansi dan seorang staf harus membandingkan jumlah setoran yang tertera pada slip setoran bank dengan jumlah yang seharusnya disetorkan. Pengendalian ini membantu memastikan bahwa seluruh kas disetorkan dan tidak ada uang kas yang hilang atau dicuri dalam perjalanan ke bank. 
3. Kas yang diterima melalui transfer dana elektronik

Kas yang diterima dari pelanggan berasal dari transferan dana elektronik, misalnya pelanggan membayar dengan menggunaka kartu kredit. Dalam hal ini, perusahaan mengirimkan formulir yang telah ditandatangani nasabah kepada nasabah bank sebagai bentuk otorisasi transfer dana elektronik bulanan. Setiap bulan, perusahaan memberi tahu pelanggan mengenai jumlah yang harus ditransfer dan tanggal transfer secara elektronik. Pada tanggal jatuh tempo, perusahaan mencatat transfer elektronis sebagai penerimaan kas ke rekening banknya dan mem-posting jumlah yang dibayarkan sebagai pengurang saldo piutang ke akun pelanggan yang bersangkutan. Kebanyakan dari perusahaan mendorong transfer elektronik otomatis oleh pelanggan untuk beberapa alasan:

a. Transfer elektronik tidak memakan biaya bila dibandingkan dengan pembayaran melalui cek ataupun giro

b. Transfer elektronik memperkuat pengendalian internal terhadap kas karena kas diterima langsung oleh bank tanpa pengelolaan kas oleh karyawan

c. Transfer elektronik mengurangi jumlah pembayaran yang terlambat dan mempercepat penerimaan kas

Berbeda halnya dengan pengendalian pembayaran kas, dalam hal ini pengendalian terhadap kas harus memberikan keyakinan yang memadai bahwa pembayaran dilakukan hanya untuk transaksi yang telah diotorisasi dan kas digunakan secara efektif serta efisien. Di perusahaan kecil, pemilik atau manajer dapat mengijinkan pembayaran berdasarkan pengetahuan pribadi mengenai barang atau jasa yang dibeli.Akan tetapi, pada perusahaan besar, tanggung jawab pembelian barang, pemeriksaan barang yang diterima, dan verifikasi tagihan biasanya dilakukan oleh karyawan yang berbeda-beda. Tanggung jawab ini harus dikoordinasikan untuk memastikan bahwa cek untuk pembayaran yang sebenarnya telah dibuat untuk kreditur. Salah satu sistem yang digunakan untuk keperluan ini yaitu dengan sistem voucher.

1. Sistem Voucher

Sistem voucher merupakan serangkaian prosedur untuk mengijinkan dan mencatat liabilitas dan pembayaran kas. Voucher adalah dokumen yang digunakan untuk memberikan bukti pemberian ijin membayar kas atau melakukan transfer dana elektronik. Tagihan yang telah 
ditandatangani dapat dianggap sebagai voucher. Akan tetapi, dalam banayk perusahaan voucher merupakan formulir khusus untuk mencatat data relevan megenai kewajiban dan rincian pembayarannya.

2. Kas yang dibayar dengan transfer data elektronik Kas yang dibayarkan melalui sistem transfer data elektronik, misalnya seseorang yang akan membayar transaksi dengan mengambil kas dari rekening bank menggunakan mesin ATM atau perusahaan membayar gaji karyawan dengan menggunakan sistem transfer kepada rekening karyawan yang bersangkutan.

\subsubsection{Aktivitas Pengendalian Internal}

Aktivitas pengendalian internal terhadap pelaporan keuangan yang dijabarkan oleh Anastasia dan Lilis $(2011,88)$ yaitu meliputi:

1. Desain Dokumen yang Baik dan Bernomor Tercetak

Aktivitas pengendalian berupa desain dokumen yang baik dan bernomor cetak merupakan desain dokumen yang dibuat secara sederhana sehingga meminimalkan kemungkinan salah dalam pengisian dokumen. Dalam desain dokumen ini pun harus memuat tempat untuk tanda tangan bagi pihak yang berwenang untuk mengotorisasi transaksi. Apabila dokumen digunakan sebagai bukti peralihan harta, maka diperlukan adanya ketersediaan kolom untuk tanda tangan dan nama terang penerima. Selain itu, dokumen pun perlu bernomor urut tercetak sehingga dapat dijadikan sebagai wujud pertanggungjawaban dokumen.

2. Adanya Pemisahan Tugas

Dalam pemisahan tugas terdapat tiga pekerjaan yang ditetapkan oleh perusahaan agar karyawan tidak memiliki peluang untuk melakukan penyalahgunaan terhadap harta perusahaan ataupun memalsukan catatan akuntansi perusahaan. Ketiga pekerjaan tersebut yaitu fungsi penyimpan harta, fungsi pencatat, dan fungsi otorisasi transaksi bisnis. Adapun uraian dari ketiga pekerjaan tersebut yaitu sebagai berikut:

a. Fungsi penyimpan harta

Dalam hal ini fungsi penyimpan harta adalah pemegang kas, pemegang persediaan yang berwenang untuk mengisi buku cek dan orang yang berwenang menyetorkan cek dari konsumen ke bank. 
b. Fungsi pencatat

Fungsi pencatat yaitu pekerjaan yang kegiatannya menyiapkan dokumen transaksi, mencatat ke dalam jurnal dan buku besar, membuat rekonsiliasi dan menyusun laporan.

c. Fungsi otorisasi transaksi bisnis

Fungsi otorisasi ini diwujudkan dalam bentuk tanda tangan dalam dokumen sebagai tindakan untuk memulai sebuah transaksi. Contoh dari fungsi otorisasi yaitu, Kepala bagian pembelian merupakan pihak yang memiliki wewenang untuk mengotorisasi transaksi pembelian yang terjadi. Sehingga surat order pembelian yang sah harus ditandatangani oleh kepala bagian pembelian.

3. Otorisasi yang Memadai atas Setiap Transaksi Bisnis yang Terjadi

Otorisasi merupakan pemberian wewenang dari manajer kepada bawahannya untuk melakukan aktivitas atau untuk mengambil keputusan tertentu. Misalnya, manajer memberi wewenang kepada kasir untuk menerima uang dari konsumen. Otorisasi ini diwujudkan dalam bentuk tanda tangan atau paraf dalam dokumen transaksi. Adakalanya perusahaan menetapkan otorisasi yang bertingkat, misalnya harus ditandatangani oleh kepala bagian pada saat melakukan pengeluaran kas kurang dari satu juta rupiah dan untuk pengeluaran di atas satu juta rupiah, harus dengan otorisasi dari manajer puncak.

4. Mengamankan Harta dan Catatan Perusahaan Harta perusahaan antara lain meliputi kas, persediaan, peralatan, sampai dengan data dan informasi perusahaan. Hal-hal yang dapat dilakukan oleh perusahaan dalam mengamankan harta dan catatan perusahaan, yaitu:

a. Menciptakan pengawasan yang memadai

b. Memastikan catatan harta yang akurat

c. Membatasi akses fisim terhadap harta (seperti penggunaan register kas, kotak brangkas, dan lain sebagainya)

d. Menjaga catatan dan dokumen dengan menyimpan catatan dan dokumen dalam lemari yang terkunci, serta dengan membuat backup yang memadai

e. Pembatasan akses terhadap ruang komputer dan terhadap file perusahaan 
5. Pengecekan Independen atas Pekerjaan Karyawan Lain

Beragam aktivitas untuk pengecekan independen atas pekerjaan karyawan lain yaitu sebagai berikut:

a. Rekonsiliasi dua catatan yang dihasilkan oleh dua pihak yang independen.

Misalnya: Rekonsiliasi antara catatan mutasi bank yang dibuat oleh akuntan perusahaan dengan laporan bak yang dibuat oleh pihak bank.

b. Membandingkan catatan dengan aktual fisik

Misalnya: perusahaan dapat membandingkan antara catatan persediaan dengan saldo persediaan yang benar-benar ada.

c. Prinsip double entry bookeeping

Dimana pada prinsip ini total debet akan sama dengan total kredit sehingga dapat dijadikan sebagai salah satu sarana pengecekan.

d. Review Independen

Misalnya pada bagian utang menyiapkan bukti kas keluar dan dalam bukti kas tersebut tertulis bahwa jumlah utang yang harus dibayar kepada pemasok senilai Rp 12.300.000 dan dilampirkan dengan 3 faktur dari pemasok. Sebelum manajer keuangan menandatangani cek senilai Rp 12.300.000, sebaiknya mengecek terlebih dulu kesesuaian jumlah faktur dari pemasok yang seharusnya dan memastikan pula bahwa selain ada faktur dari pemasok, terdapat juga Bukti Penerimaan Barang.

\subsubsection{Bentuk Pengendalian Internal Kas}

Pengendalian internal kas yang dijabarkan oleh Warren et. al (2008, 323), yaitu setiap terjadinya pengeluaran atau pembayaran yang menggunakan kas harus memberikan jaminan yang memadai bahwa pembayaran tersebut dilakukan dengan adanya otorisasi. Biasanya, perusahaan menggunakan sistem voucher sebagai serangkaian prosedur yang digunakan untuk mengotorisasi dan membukukan kewajiban atau pembayaran kas serta digunakan untuk mencatat data yang relevan mengenai kewajiban ataupun pembayaran kas perusahaan.

Pada setiap voucher dicantumkan nomor faktur kreditur atau pemasok dan jumlah serta syarat faktur. Akun-akun yang digunakan untuk mencatat 
pembayaran dicantumkan pada distribusi akun. Biasanya voucher disiapkan di Departemen Akuntansi setelah semua dokumen pendukung yang diperlukan diterima. Apabila terjadi pembelian barang maka voucher disiapkan, dan harus didukung dengan adanya faktur dari pemasok, pesanan pembelian, dan laporan penerimaan barang. Dalam menyiapkan voucher, petugas utang usaha meneliti kuantitas harga dan keakuratan laporan pada dokumen pendukung. Hal tersebut dilakukan untuk memberikan jaminan bahwa pembayaran yang dilakukan untuk barang yang dipesan dan diterima sudah sesuai.

Setelah voucher dan dokumen pendukung disiapkan maka disampaikan kepada pejabat yang berwenang untuk mendapatkan persetujuan. Apabila disetujui, voucher dikembalikan ke Departemen Akuntansi untuk dicatat dalam akun. Selanjutnya, voucher diarsipkan pada arsip khusus berdasarkan tanggal jatuh tempo. Pada tanggal jatuh tempo, voucher dipindahkan dari arsip voucher yang belum dibayar, kemudian tanggal, nomor dan jumlah cek dituliskan di belakang voucher.

Pembayaran atas voucher kemudian dibukukan sebagaimana halnya dengan pembayaran utang usaha. Setelah selesai, maka voucher dibubuhkan cap "LUNAS" dan diarsipkan berdasarkan nomor urut pada arsip yang sudah dibayar. Arsip voucher dapat dijadikan sebagai informasi bagi karyawan mengenai pembayaran di masa lalu.

Contoh dari voucher tersebut disajikan pada gambar sebagai berikut:

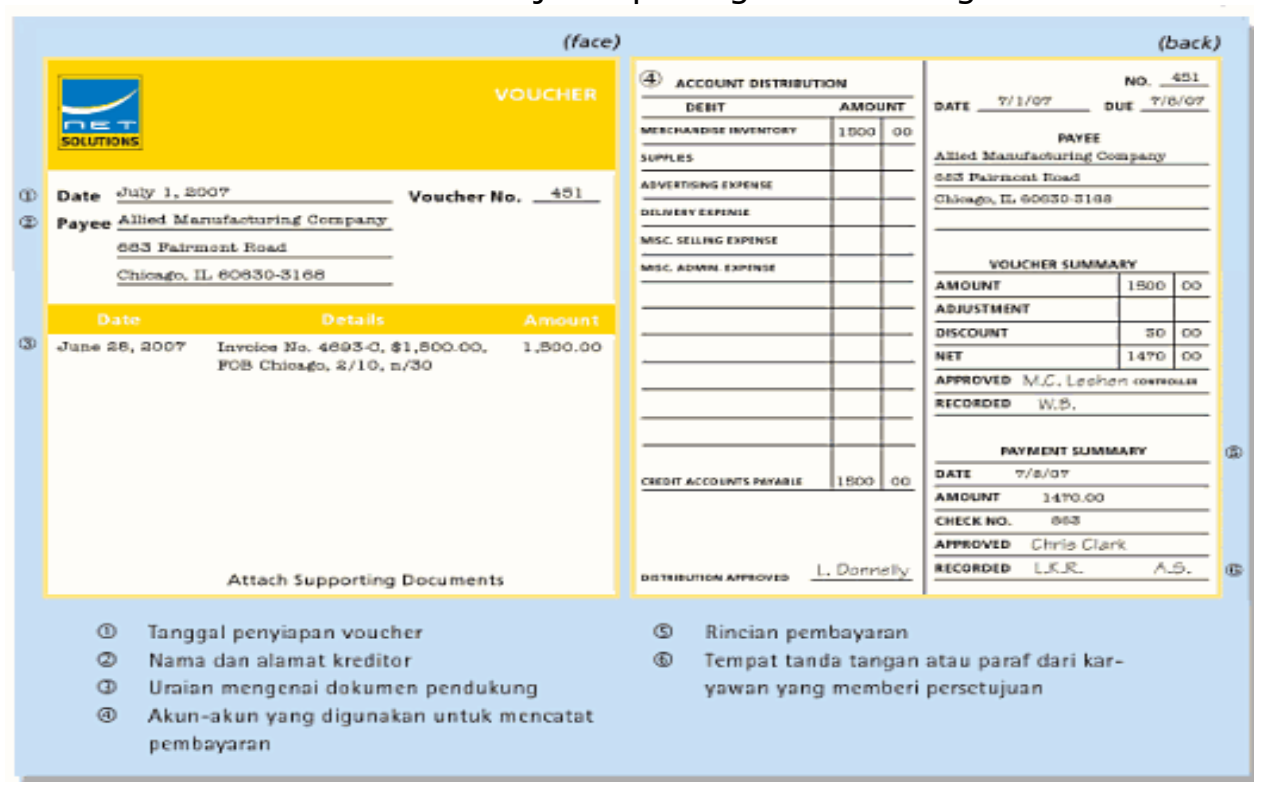

Gambar 2.1

Voucher Pembayaran kas

Sumber : Pengantar Akuntansi Edisi 21 (Warren et. al, 2008, 325) 


\subsubsection{Tujuan Pengendalian Internal Kas}

Waluyo $(2008,50)$ menilai bahwa pengendalian internal kas sangat berguna untuk melindungi kas dari penyalahgunaan, karena kas sangat mudah dipindahtangankan dan mungkin tidak dapat dibuktikan kepemilikannya. Selain itu, Anastasia dan Lilis $(2011,83)$ pun menilai dengan adanya pengendalian internal kas, perusahaan dapat mencapai keefektifan operasi serta memperoleh laporan yang realibilitas.

Berbeda halnya dengan pendapat Kieso et al. (2011, 373), tujuan dari adanya sistem pengendalian internal kas yaitu "to safeguard cash and to ensure the accuracy of the accounting record for cash". Pendapat tersebut pun didukung oleh pendapat Warren et al. (2008, 208), yang menyatakan bahwa dengan adanya pengendalian internal kas dapat memberikan jaminan yang memadai bahwa aset sudah dilindungi dan digunakan untuk mencapai tujuan usaha, serta dijadikan sebagai infomasi bisnis yang akurat sehingga menjadikan karyawan dapat mematuhi peraturan dan ketentuan yang berlaku.

Dengan demikian, maka tujuan dari pengendalian internal kas adalah untuk melindungi kas dari terjadinya penyalahgunaan, sehingga dapat dijadikan sebagai infomasi bisnis yang akurat untuk memperoleh laporan keuangan perusahaan yang realibilitas dan sesuai dengan aturan yang berlaku.

\subsubsection{Pengertian Dana Kas Kecil}

Dana kas kecil menurut Horngren (2007, 409) yaitu uang yang disediakan oleh perusahaan dan digunakan untuk melakukan pembayaranpembayaran dalam jumlah yang relatif kecil. Pembentukan kas kecil pada suatu perusahaan dinilai lebih efisien karena dapat digunakan untuk membiayai pembayaran yang relatif kecil, seperti yang diungkapkan oleh Wilson et al. (2011, 266), yaitu "petty cash is more efficient for business to keep a small amount of cash on hand to make these small value payment".

Menurut Rudianto $(2012,188)$, yaitu "kas kecil adalah uang tunai yang disediakan perusahaan untuk membayar pengeluaran-pengeluaran yang jumlahnya relatif kecil dan tidak ekonomis bila dibayar menggunakan cek". Selain itu, Warren et al. $(2014,418)$ pun menilai bahwa dana kas kecil lebih praktis daripada cek untuk membiayai kegiatan yang sering terjadi. 
Keempat pengertian tersebut di atas, di dukung pula oleh pendapat Johar Arifin $(2009,45)$ yang menjabarkan bahwa kas kecil merupakan dana yang disisihkan oleh suatu perusahaan untuk membiayai pengeluaranpengeluaran yang terjadi dengan jumlah yang relatif kecil.

Oleh karena itu, berdasarkan uraian tersebut di atas maka dapat disimpulkan bahwa kas kecil merupakan sejumlah dana khusus yang disediakan oleh suatu perusahaan, dimana dana tersebut digunakan untuk membiayai pengeluaran-pengeluaran yang bersifat rutin dengan jumlah yang relatif kecil.

\subsubsection{Sistem dan Prosedur Pengelolaan Dana Kas Kecil}

Sistem dan prosedur pengelolaan dana kas kecil merupakan serangkaian kegiatan atau tahapan-tahapan yang dibuat oleh perusahaan dan dirancang untuk mengatur pengelolaan dana kas kecil, mulai dari pembentukan, penggunaan, sampai dengan melakukan pengisian kembali dana kas kecil. Adapun uraian sistem dan prosedur pengelolaan dana kas kecil yaitu sebagai berikut:

1. Pembentukan dana kas kecil

Menurut Harrison et al.(2012, 255), pembentukan dana kas kecil diawali dengan jumlah kas tertentu, dimana jumlah besaran tersebut berdasarkan kebijakan masing-masing perusahaan dengan memperkirakan jumlah kas yang diperlukan untuk pembayaran selama periode tertentu, misalnya satu minggu, dua minggu atau satu bulan. Pengajuan pembentukan dana kas kecil ini harus disetujui oleh pihak yang berwenang, biasanya dalam hal ini adalah manajer keuangan. Setelah pengajuan pembentukan dana kas kecil disetujui, cek ditulis dan diuangkan sebesar jumlah perkiraan. Uang dari cek tersebut kemudian diberikan kepada bagian pemegang kas.

2. Pengeluaran kas kecil

Nuraida (2008, 138) menjabarkan bahwa, apabila terjadi pengeluaran pada kas kecil, maka staf yang meminta dana untuk membeli barang yang diperlukan perusahaan harus mengisi advance petty cash voucher secara detail. Pada advance petty cash voucher terdapat nomor formulir, tanggal terjadinya 
pengeluaran, perkiraan, uraian atau keterangan mengenai barang yang dibeli, jumlah pengeluaran dalam rupiah, disetujui oleh pihak yang berwenang dalam pengeluaran kas kecil, tanda tangan penerima uang, tanda tangan yang mengeluarkan uang kas. Format yang sudah terisi diserahkan kepada pihak yang berwenang untuk disetujui terlebih dulu. Apabila format disetujui, pemegang kas kecil memberikan sejumlah uang yang tercantum pada advance petty cash voucher. Setelah pembelian barang selesai, maka staf menyerahkan kuitansi pembelian kepada pemegang kas kecil. Harga pembelian barang bisa lebih rendah atau lebih tinggi dari jumlah harga yang diperkirakan. Jika lebih rendah, maka staf harus mengembalikan kelebihan dana tersebut, sedangkan jika harga lebih tinggi maka pemegang kas kecil menambah kekurangannya. Apabila hal tersebut terjadi kasir harus mengisi petty cash voucher berdasarkan nama barang serta harga yang tertera pada kuitansi. Formulir-formulir tersebut kemudian disimpan oleh pemegang kas kecil untuk melakukan pembukuan yang dilengkapi dengan bukti-bukti pembayaran dari pembelian yang dilakukan oleh staf. Bukti-bukti pembayaran tersebut digunakan sebagai lampiran saat melakukan pengisian kembali dan kas kecil. Bagan alir prosedur pengeluaran dana kas kecil yang dijabarkan oleh Ida Nuraida $(2008,139)$ dapat dilihat pada gambar 2.2. 


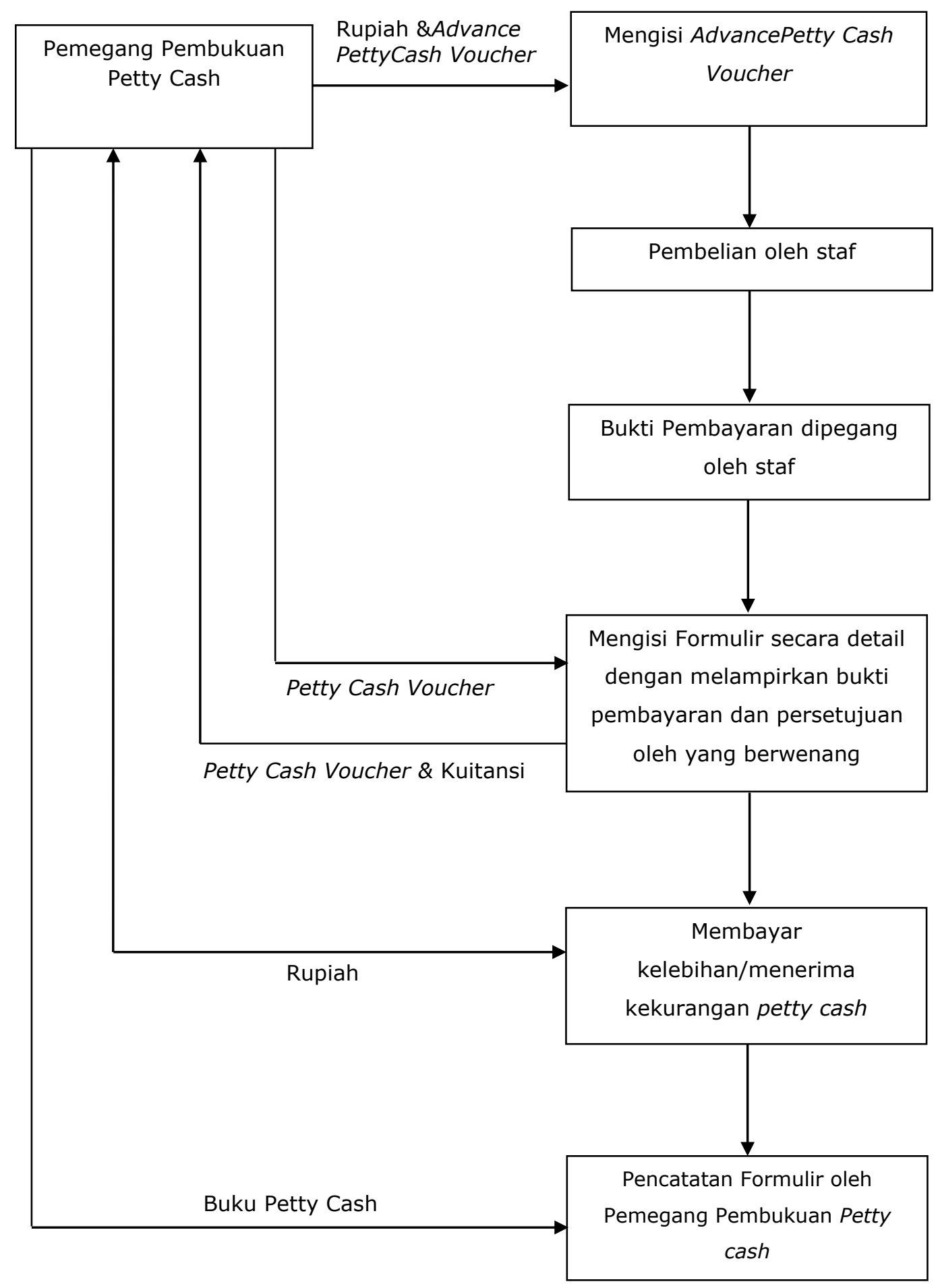

Gambar 2.2

Prosedur Pengeluaran Kas Kecil

Sumber : Manajemen Administrasi Perkantoran (Ida Nuraida, 2008, 139) 
3. Pengisian kembali dana kas kecil

Pengisian dana kas kecil tergantung dari kebijaksanaan masingmasing perusahaan dan dilakukan per periode misalnya, satu minggu sekali, dua minggu sekali atau satu bulan sekali. Jika jumlah dana kas kecil sebelum akhir periode maupun pada akhir periode telah mencapai jumlah minimum, maka dapat dilakukan pengisian kembali sesuai sistem yang digunakan oleh perusahaan. Jika perusahaan menggunakan metode imprest, maka pengisian dana sebesar jumlah yang sudah dikeluarkan kas sehingga jumlah kas kecil akan kembali seperti semula, sedangkan jika menggunakan metode fluktuasi maka pengisian dana disesuaikan dengan kebutuhan perusahaan. Pengisiaan pada metode fluktuasi bisa lebih besar atau lebih dari dana yang sudah dikeluarkan. Pada saat dana kas kecil menipis, kasir mengajukan dana dan melampirkan bukti-bukti pembayaran yang sudah dilakukan. Jika pengajuan dana kas kecil ini sudah disetujui oleh pihak yang berwenang, maka kasir kas kecil akan memperoleh cek sejumlah dana yang diajukan (Nuraida, 2008, 137).

\subsubsection{Sistem Pencatatan Dana Kas Kecil}

Waluyo $(2008,51)$ menjabarkan dua metode sistem pencatatan dana kas kecil, yaitu metode imprest dan metode fluktuasi. Metode imprest merupakan metode pengisian dan pengendalian kas kecil dimana jumlah kas kecil akan selalu tetap dari waktu ke waktu karena pada saat melakukan pengisian kembali, dana yang diajukan selalu sama dengan jumlah yang sudah dikeluarkan. Penggunaan kas kecil yang pada metode imprest tidak memerlukan pencatatan jurnal atas setiap transaksi yang terjadi. Pada metode ini hanya mengumpulkan bukti-bukti transaksi dan diserahkan oleh kasir pada saat pengisian kembali kas kecil. Jumlah nominal dari keseluruhan dari bukti-bukti transaksi akan menjadi saldo pengisian kas kecil pada periode selanjutnya.

Berbeda halnya dengan metode fluktuasi, metode ini merupakan metode pencatatan dan pengendalian kas kecil, dimana jumlah kas kecil akan selalu berubah, karena pada saat pengisian kembali jumlah besaran yang diajukanakan disesuaikan dengan kebutuhan perusahaan. Perbedaan lainnya 
dengan metode imprest yaitu setiap terjadinya pengeluaran, metode fluktuasi harus melakukan pencatatan atau penjurnalan yang berdasarkan atas buktibukti transaksi yang ada dan dicatat satu per satu.

Berdasarkan penjelasan tersebut di atas, maka perbedaan antara metode imprest dengan metode fluktuasi dapat dilihat pada tabel 2.1.

Tabel 2.1

Perbedaan Metode Pencatatan Kas

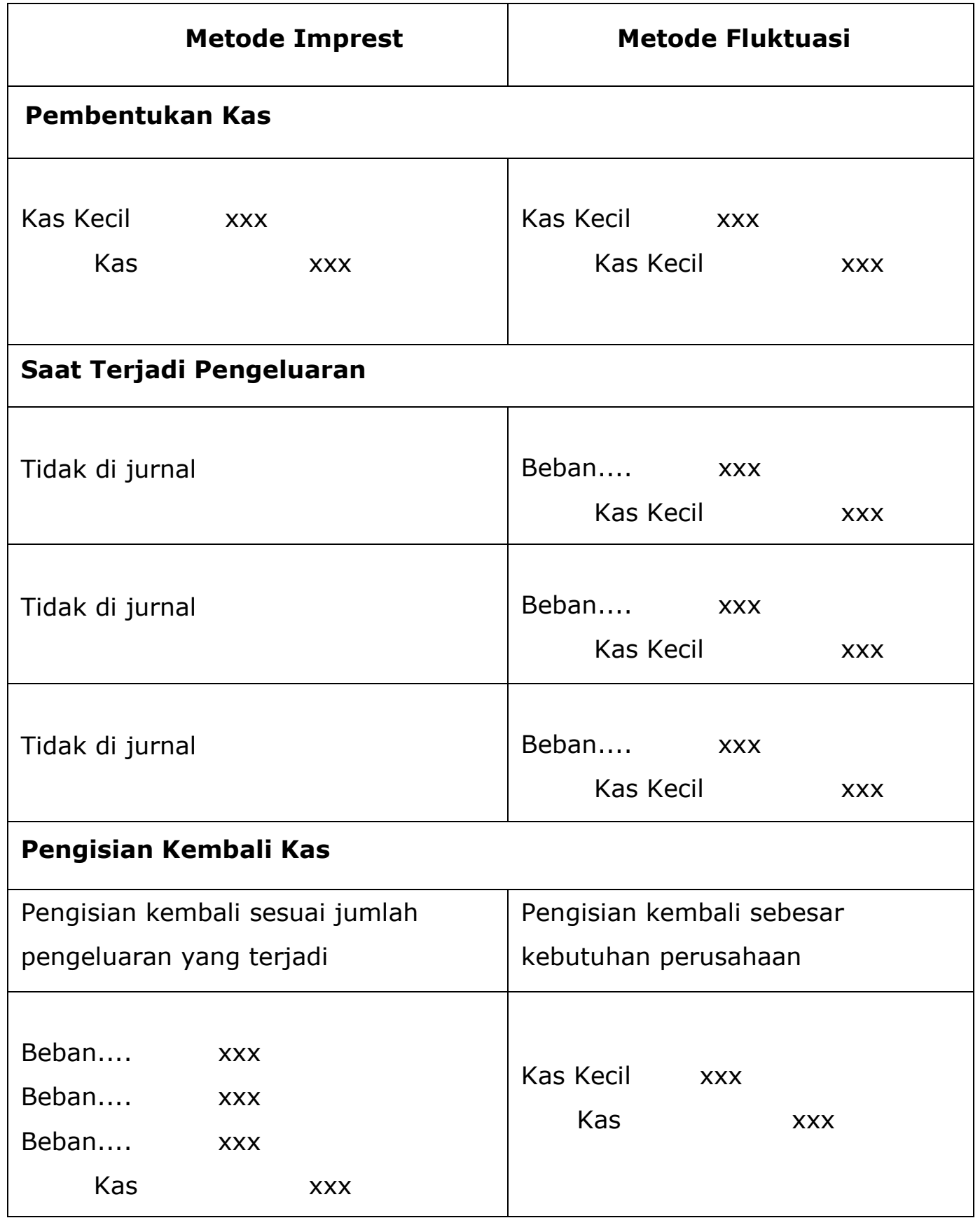

Sumber : Waluyo, Akuntansi Pajak $(2008,51)$ 


\subsubsection{Resiko dalam Kas Kecil}

Kas kecil meskipun dana yang disediakan oleh perusahaan dengan jumlah yang relatif kecil, namun tetap akan menghadapi resiko. Resiko akan terjadi apabila pengelolaan dana kas kecil tersebut tidak memiliki sistem pengendalian yang baik. Resiko yang terjadi pun akan mengakibatkan kerugian yang besar pada perusahaan.

Adapun penyebab-penyebab terjadinya resiko dana kas kecil pada suatu perusahaan yang dijabarkan oleh Anastasia dan Lilis $(2011,160)$ yaitu sebagai berikut:

1. Nota Kosong

Nota kosong biasanya digunakan atau dimanfaatkan oleh karyawan untuk menarik dana dari perusahaan. Penggunaan nota kosong ini dilakukan untuk memperoleh keuntungan pribadi. Karyawan biasanya melaporkan nota dengan nominal yang lebih tinggi dari yang sebenarnya atau melaporkan nota yang tidak ada transaksi terkait yang riil.

Misalnya : Anwar adalah staf administrasi PT. XYZ. Anwar mengajukan pengeluaran kepada kasir untuk membeli cartridge printer. Kasir menyerahkan uang sebesar Rp 1.000.000 kepada Anwar. Akan tetapi, nilai transaksi yang sebenarnya terjadi yaitu hanya sebesar Rp 700.000. Namun, Anwar meminta nota kosong pada penjual cartridge dan mencantumkan harga senilai $\mathrm{Rp}$ 850.000. Selisih dari uang tersebut senilai Rp 150.000, diserahkan oleh Anwar kepada BPP bersama dengan nota transaksi tersebut.

2. Pengelola kas memiliki godaan untuk "meminjam" uang sebentar dari dana kas, terutama sesaat setelah pengisian kas.

Misalnya: Kasir akan membeli makan siang untuk keperluan pribadi, tetapi kasir tersebut tidak memegang uang tunai sehingga kasir meminjam uang kas perusahaan. Kasir tidak mencatat uang yang dipinjam tersebut, sehingga kemungkinan besar dapat mengakibatkan kasir lupa untuk mengembalikan.

3. Kas bon yang tidak pernah diselesaikan oleh karyawan karena malas menyelesaikan, terutama jika karyawan bertugas luar. Apabila perusahaan tidak ketat dalam mengawasi karyawan yang mengajukan kas bon, kemungkinan besar karyawan yang bersangkutan menunda untuk menyelesaikan kas bon, walaupun 
sebenarnya pembelian terkait dengan kas bon tersebut sudah selesai dilakukan. Perusahaan sebaiknya dalam hal ini tidak memberikan toleransi bagi karyawan yang selalu menunda penyelesaian kas bon, karena dikhawatirkan karyawan memanfaatkan "meminjam" uang sisa kas bon. Sekali terjadi seorang karyawan menikmati "pinjam uang" dan tidak ada masalah, maka kebiasaan ini dapat sering terjadi.

Misalnya : Perusahaan meminjamkan uang kepada Ridho sebesar Rp 850.000. Ridho harus mengganti setiap tanggal 8, dalam kurun waktu 10 bulan dengan cicilan sebesar Rp 85.000. Bulan pertama sampai dengan bulan kedua, pembayaran kas bon tersebut masih lancar, tetapi pada bulan ketiga Ridho menunda pembayaran kas bon. Alasan Ridho menunda pembayaran yaitu ada keperluan lain yang harus segera diselesaikan, dan perusahaan pun memakluminya. Namun, dengan adanya kebijakan perusahaan, Ridho menjadi terbiasa menunda pembayaran kas bon karena mengganggap kebiasaannya tersebut dapat ditoleransi.

Resiko lainnya yang dapat terjadi pada kas kecil yaitu terjadinya selisih dana kas kecil. Selisih dana kas kecil merupakan perbedaan antara jumlah kas menurut penghitungan fisik dengan catatan kas yang ada pada rekening bank maupun catatan buku besar kas pada perusahaan. Penyebab terjadinya selisih kas kecil yaitu adanya uang palsu, kehilangan akibat kekeliruan saat transaksi penjualan tunai, adanya penerimaan atau pembayaran yang ada nilai recehannya, kesalahan pencatatan yang dilakukan baik pada saat melakukan penerimaan kas maupun pada saat melakukan pengeluaran kas, dan sebab lainnya yang sama sekali tidak dapat diketahui (http://elearningman1mdn.blogspot.com).

Oleh karena itu, untuk menghindari resiko-resiko yang dapat terjadi pada kas kecil maka perusahaan harus menjalankan sistem dan prosedur yang berlaku pada perusahaan, agar setiap kegiatan yang mempengaruhi dana kas dapat berjalan sesuai dengan sistem dan prosedurnya. Selain itu, diperlukan juga adanya ketelitian pada bagian yang terkait langsung dengan pengelolaan dana kas kecil. 



\section{BAB III \\ HASIL DAN BAHASAN}

\subsection{Sejarah Organisasi}

Proses pembentukan Jurusan/Departemen Konservasi Sumberdaya Hutan Fakultas Kehutanan IPB dikoordinasikan oleh Panitia Pembentukan Departemen Konservasi Sumberdaya Hutan berdasarkan SK Dekan Fakultas Kehutanan Nomor 08 Tahun 1981 pada tanggal 26 Juni 1980.Untuk mematangkan dan menyempurnakan konsep yang telah disusun, maka pada tanggal 14 September 1982 diadakan Lokakarya Pemantapan Departemen Konservasi Sumberdaya Hutan di Kampus IPB Darmaga Bogor.

Lokakarya Pemantapan Departemen Konservasi Sumberdaya Hutan melibatkan para pihak yang berkepentingan, yaitu Fakultas Kehutanan IPB, Fakultas Kedokteran Veteriner IPB, PUSDIK-PSL IPB, PPLH, Universitas Gajah Mada Yogyakarta, Universitas Mulawarman Samarinda, Balai Penelitian Hutan, BPLPP, Balai Latihan Kehutanan, Direktorat Pengusahaan Hutan, BPLPP, Balai Latihan Kehutanan, Direktorat Perlindungan dan Pengawetan Alam, School of Environmental Conservation Management Ciawi, Perum Perhutani, Direktorat Pengusahaan Hutan, Forestry Centre, Museum Zoologi, Bogoriensis dan Lembaga Biologi Nasional-LIPI.

Berdasarkan hasil lokakarya tersebut semua pemangku kepentingan (peserta lokakarya) menyatakan perlunya segera dibentuk sebuah Jurusan/Program Studi baru di lingkup Fakultas Kehutanan IPB dengan nama "Jurusan/Program Studi Konservasi Sumberdaya Hutan". Program Studi ini merupakan program studi pertama di Indonesia dalam bidang Konservasi Sumberdaya Hutan yang secara resmi didirikan berdasarkan Surat Keputusan Rektor IPB Nomor 103 Tahun 1982 tanggal 14 November 1982.

Pendirian Program Studi ini diakui oleh pemerintah dengan Keputusan Direktorat Jenderal Tinggi Departemen Pendidikan dan Kebudayaan Nomor 048/DJ/Kep/1982 tanggal 4 Oktober 1982 tentang Program Studi pada Perguruan Tinggi serta Keputusan Direktorat Jenderal Pendidikan Tinggi Departemen Pendidikan dan Kebudayaan Nomor 137/DIKTI/Kep/1984 tanggal 22 November 1984 tentang Jenis dan Jumlah Program Studi di setiap Program Studi pada Fakultas di Lingkungan Institut Pertanian Bogor. 
Pada saat IPB menerapkan kurikulum mayor-minor pada tahun 2005, juga dilakukan penataan departemen, sehingga Jurusan/Program Studi Konservasi Sumberdaya Hutan menjadi Departemen/Program Studi Konservasi Sumberdaya Hutan dan Ekowisata berdasarkan SK Rektor No. 112/K13/OT/2005 dan SK Rektor IPB No. 224/K13/OT/2005.

\subsubsection{Visi dan Misi Departemen KSHE}

Visi Departemen Konservasi Sumberdaya Hutan dan Ekowisata (DKSHE), yaitu:

"Menjadi pusat pengembangan ilmu pengetahuan, teknologi dan seni (IPTEKS) dan sumberdaya manusia di bidang konservasi keanekaragaman hayati tropika dan lingkungan hidup".

Penjabaran lebih lanjut visi DKSHE tersebut ke dalam tiga tingkatan, yaitu:

Global : Menghasilkan sumberdaya manusia yang profesional untuk mengimplementasikan inisiatif konservasi yang efektif yang mampu menjawab permasalahan dalam bidang keanekaragaman hayati dan lingkungan hidup.

Nasional : Memberikan kontribusi dalam peningkatan kuantitas dan kualitas sumberdaya manusia guna tercapainya tujuan pembangunan daerah dan nasional yang bertumpu pada sumberdaya hayati secara berkelanjutan.

Lokal : Memainkan peran kunci dalam kaitannya dengan kemitraan dengan pemerintah, bisnis serta industri dalam mengembangkan masyarakat.

Berdasarkan pertimbangan-pertimbangan tersebut maka misi DKSHE adalah:

1. Menyelenggarakan dan mengembangkan pendidikan akademik dan profesi berbasis penelitian di bidang konservasi keanekaragaman hayati tropika dan lingkungan hidup.

2. Menyelenggarakan dan mengembangkan penelitian berorientasi pada pengembangan IPTEKS dan pemecahan masalah di bidang konservasi keanekaragaman hayati tropika dan lingkungan hidup, sehingga mampu menjawab tantangan dan permasalahan riil dan tuntutan kebutuhan masyarakat/pengguna. 
3. Memfasilitasi penerapan IPTEKS di bidang konservasi keanekaragaman hayati tropika dan lingkungan hidup bagi masyarakat secara berkelanjutan, termasuk diantaranya pengembangan ekowisata.

4. Mewujudkan DKSHE sebagai penentu kecenderungan (trend setter) dalam kebijakan dan pengembangan konservasi keanekaragaman hayati tropika dan lingkungan hidup bagi masyarakat profesi yang berkecimpung dalam dunia ilmu pengetahuan, dunia usaha, lembaga swadaya masyarakat maupun pemerintahan

\subsection{Struktur Organisasi dan Uraian Tugas}

\subsubsection{Struktur Organisasi}

Struktur organisasi Departemen Konservasi Sumberdaya Hutan dan Ekowisata (DKSHE) selaku Pengelola atau homebase secara garis besar dapat dibedakan ke dalam dua bentuk, yaitu hubungan secara struktural dan fungsional.Secara struktural (lihat gambar 3.2.1.1), pimpinan departemen membawahi sekretaris departemen, kepala tata usaha, dan membawahi tenaga penunjang administrasi dan tenaga penunjang akademik lainnya. Jika dilihat dari segi fungsional (lihat gambar 3.2.1.2) pimpinan Departemen tidak hanya membawahi sekretaris departemen, kepala tata usaha, tenaga penunjang administrasi dan tenaga penunjang akademik, tetapi juga membawahi lima bagian, yaitu Bagian Ekologi dan Manajemen Satwa Liar, Bagian Konservasi Tumbuhan Obat, Bagian Hutan Kota dan Jasa Lingkungan, Bagian Manajemen Kawasan Konservasi dan Bagian Rekreasi Alam dan Ekowisata.

Masing-masing bagian membawahi laboratorium/studio yang terdiri dari enam laboratorium/studio, yaitu Laboratorium Ekologi Satwa liar, Laboratorium Konservasi Ex-Situ Satwa Liar, Laboratorium Hutan Kota dan Analisis Spasial Lingkungan, Laboratorium Konservasi Tumbuhan, Studio Pengelolaan Kawasan Konservasi dan Studio Rekreasi Alam.Di samping itu, Ketua Departemen membawahi satu program studi sarjana (S1) dan 3 (tiga) program studi pascasarjana (sebagaimana diatur dalam SK Rektor IPB No. 027/KI3/PP/2007 tentang penetapan homebase PS Pascasarjana, yaitu Program Studi Konservasi Biodiversitas Tropika (S2 dan S3), Program Studi Manajemen Ekowisata dan Jasa Lingkungan(S2 dan S3) dan Program Studi Magister Konservasi Keanekaragaman Hayati (S2 Terapan). Setiap program 
studi dipimpin oleh ketua dan sekretaris program studi.Dalam pelaksanaan tugasnya, pimpinan Departemen dibantu oleh Sekretaris Departemen dan empat komisi yaitu Komisi Pendidikan, Komisi Kemahasiswaan dan Alumni, Komisi Publikasi IImiah dan Komisi Praktek Kerja Lapang.

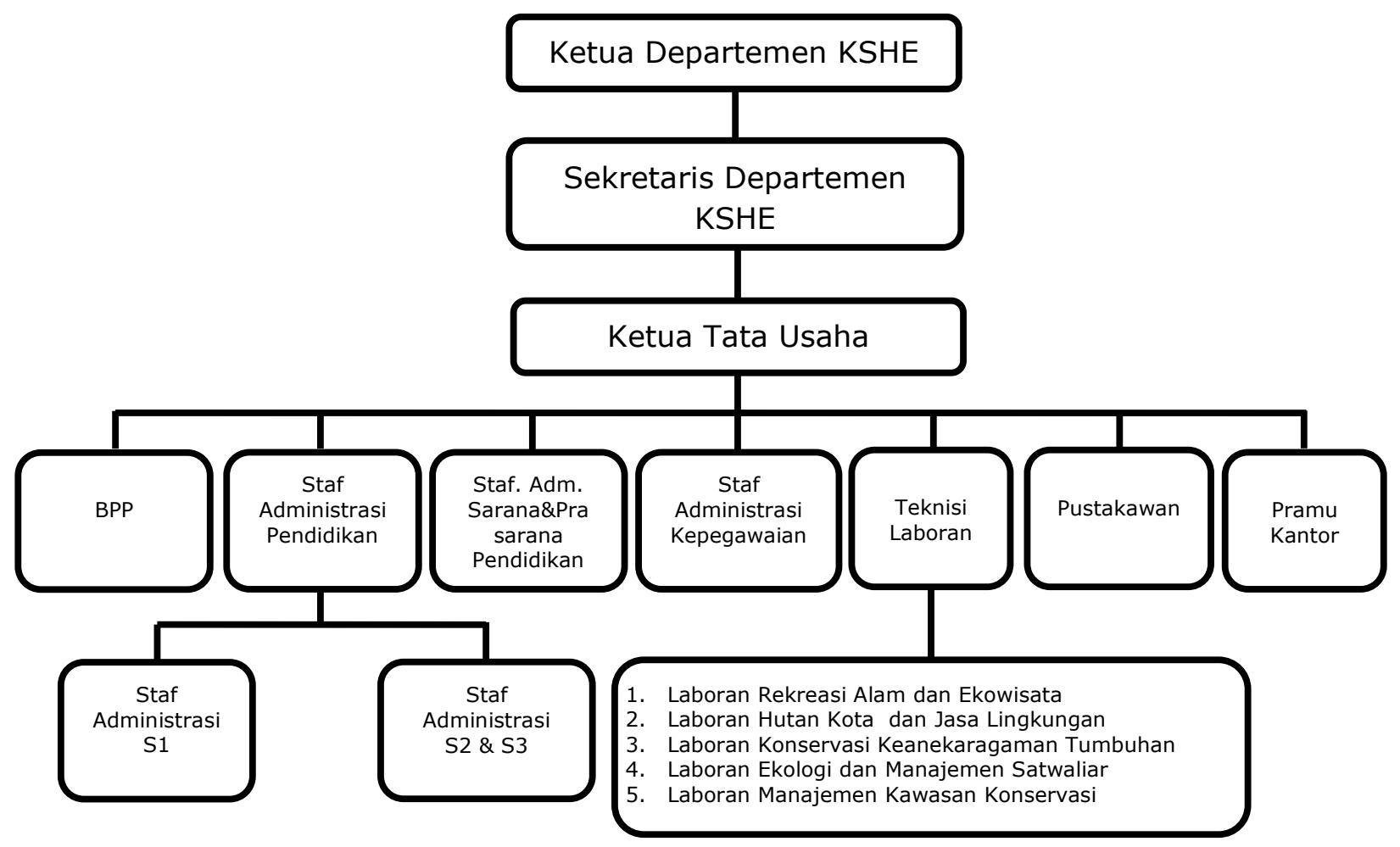

Gambar 3.1

Struktur Organisasi DKSHE Secara Struktural 


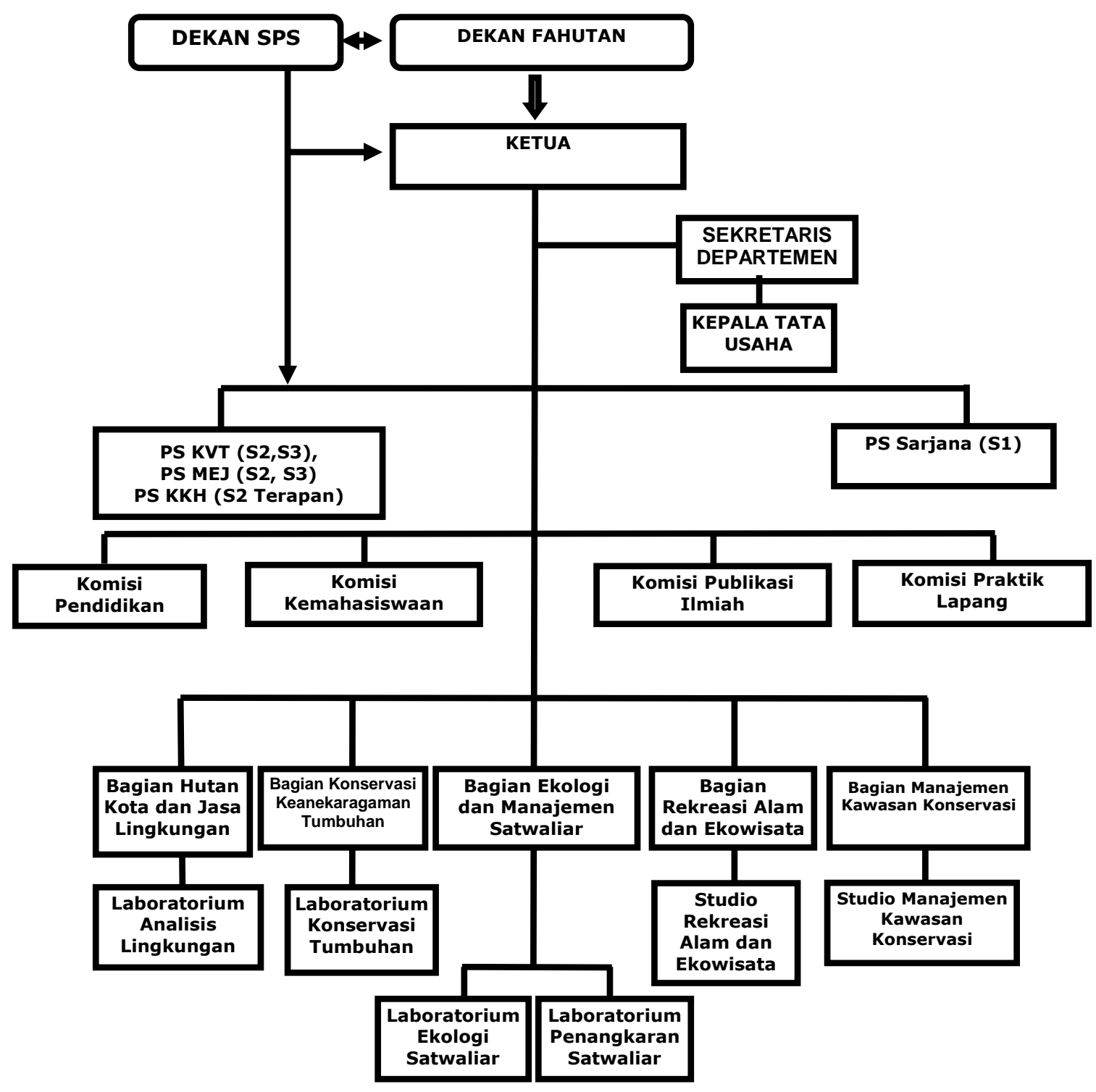

Keterangan :

KVT : Konservasi Biodiversitas Tropika

MEJ : Manajemen Ekowisata dan Jasa Lingkungan

$\mathrm{KKH}$ : Konservasi Keanekaragaman Hayati

Gambar 3.2

Struktur Organisasi DKSHE Secara Fungsional 


\subsubsection{Uraian Tugas}

1. Ketua Departemen

Berdasarkan SK Rektor IPB No. 148/13/OT/2009, tugas pokok dan fungsi (tupoksi) Ketua Departemen adalah sebagai berikut :

a. Tugas pokok

Mengkoordinasikan pelaksanaan kegiatan akademik di tingkat departemen baik untuk Program Pendidikan Sarjana (S1), Magister (S2) maupun Doktor, dan mengkoordinasikan pelaksanaan kegiatan pengembangan keilmuan yang dilakukan oleh bagian dalam rangka mencapai keunggulan akademik (academic excellent).

b. Fungsi

Mengkoordinasikan pelaksanaan kegiatan akademik yang dilakukan oleh dosen sesuai dengan mandat, dan mayor yang ditawarkan oleh departemen, mengkoordinasikan pelaksanaan kegiatan pengembangan keilmuan yang dilakukan oleh bagian sesuai dengan mandat departemen dan melaksanakan manajemen departemen yang meliputi pembinaan tenaga pendidik (dosen), kegiatan profesi mahasiswa, dan pelaksanaan kerjasama akademik dengan mitra kerja.

Sesuai dengan tugas pokok dan fungsi, maka rincian tugas dari ketua departemen yaitu:

1. menyusun rencana dan program kerja departemen;

2. mengkoordinasikan pelaksanaan kegiatan akademik yang dilakukan oleh dosen sesuai dengan mandat, dan mayor yang ditawarkan oleh departemen yang meliputi kegiatan pendidikan, penelitian dan pengabdian kepada masyarakat;

3. mengevaluasi kegiatan akademik departemen (pendidikan, penelitian dan pengabdian kepada masyarakat);

4. mengkoordinasikan pelaksanaan kegiatan pengembangan keilmuan yang dilakukan oleh bagian sesuai dengan mandat departemen;

5. membina kegiatan dan organisasi profesi mahasiswa di departemen;

6. melaksanakan kerjasama akademik dengan mitra kerja; 
7. mengarahkan Sekretaris Departemen dalam pelaksanaan manajemen departemen;

8. membina tenaga pendidik (dosen) di departemen;

9. menyusun rencana biaya operasional tahunan dan laporan kegiatan departemen sesuai dengan ketentuan yang berlaku.

\section{Sekretaris Departemen}

Tugas pokok dan fungsi Sekretaris Departemen di dalam lingkungan Institut Pertanian Bogor adalah:

a. Tugas pokok

Membantu ketua departemen mengkoordinasikan pelaksanaan kegiatan akademik di tingkat departemen, pengembangan keilmuan bagian, dan melaksanakan manajemen departemen dalam rangka meningkatkan kinerja dan kelancaran pelaksanaan kegiatan departemen.

b. Fungsi

Membantu ketua departemen dalam mengkoordinasikan pelaksanaan kegiatan akademik yang dilakukan oleh dosen sesuai dengan mandat dan mayor yang ditawarkan oleh departemen. mengkoordinasikan pelaksanaan, membantu Ketua Departemen dalam mengkoordinasikan pelaksanaan kegiatan pengembangan keilmuan yang dilakukan oleh bagian di lingkungan departemennya sesuai dengan mandat departemen dan melaksanakan manajemen departemen yang meliputi pembinaan tenaga kependidikan, administrasi departemen, dan penanganan kebersihan, ketertiban dan keamanan di lingkungan departemen.

Sesuai dengan tugas pokok dan fungsi tersebut di atas, maka rincian dari tugas Sekretaris Departemen yaitu sebagai berikut:

1. Membantu atau mewakili Ketua Departemen dalam mengkoordinasikan pelaksanaan kegiatan akademik departemen, pengembangan keilmuan bagian dan kegiatan kemahasiswaan, pelaksanaan kerjasama akademik dengan mitra kerja, dan pelaksanaan tugas manajemen lainnya yang menjadi tanggung jawab Ketua Departemen;

2. Mengarahkan Kepala Tata Usaha Departemen dalam penataan dan pelaksanaan administrasi departemen; 
3. Membina tenaga kependidikan di departemen;

4. Mengarahkan Kepala Tata Usaha Departemen dalam penanganan kebersihan, ketertiban dan keamanan di lingkungan departemen

3. Ketua Tata Usaha

Tugas pokok Kepala Tata Usaha pada Departemen Konservasi Sumberdaya Hutan dan Ekowisata, yaitu sebagai berikut:

a. Menyusun rencana dan program kerja tata usaha Departemen secara periodik (bulanan);

b. Memberikan tugas dan mengevaluasi kinerja pegawai administrasi dalam melaksanakan kegiatan sesuai dengan tugasnya;

c. Mengkoordinir, monitoring dan evaluasi proses kenaikan pangkat Staf Pengajar dan Tenaga Kependidikan;

d. Mengkoordinir, monitoring dan evaluasi pelayanan perkuliahan;

e. Mengkoordinir dan monitoring pengelolaan nilai mahasiswa;

f. Verifikasi surat keluar

g. Distribusi surat masuk;

h. Membuat konsep surat;

i. Verifikasi dan monitoring laporan keuangan departemen;

j. Panitia pelaksana UTS dan UAS program S1;

k. Menandatangani form clearing mahasiswa;

I. Mengevaluasi dan meningkatkan mutu pelaksanaan kegiatan administrasi dan akademik;

m. Menyusun rencana biaya operasional bulanan berdasarkan ketentuan yang berlaku;

n. Melakukan rencana biaya operasional bulanan berdasarkan ketentuan yang berlaku;

o. Melakukan penilaian kinerja tenaga penunjang secara periodik (bulanan);

p. Melaporkan hasil pelaksanaan tugas kepada atasan;

q. Melaksanakan tugas kedinasan lainnya sesuai dengan petunjuk pimpinan departemen;

4. Bendahara Pengeluaran Pembantu

Bendahara Pengeluaran Pembantu (BPP) merupakan pegawai yang ditunjuk dan diberikan tugas untuk mengelola dana kas yang ada pada 
Departemen. Tugas dari Bendahara Pengeluaran Pembantu yaitu sebagai berikut:

a. Menyusun usulan pengajuan uang persediaan (UP), tambahan uang persediaan (TUP), langsung (LS) dan gaji sesuai dengan program serta kegiatan yang dilakukan;

b. Menerima dan menatausahakan UP/TUP dari bendahara pengeluaran sesuai dengan ketentuan yang berlaku;

c. Melakukan pengujian dan pembayaran atas tagihan yang dananya bersumber dari UP/TUP;

d. Melakukan pemotongan/pemungutan dan penyetoran pajak dari pembayaran yang dilakukan sesuai dengan ketentuan;

e. Menyerahkan surat setoran pajak kepada BP;

f. Melakukan pencatatan buku di kas umum sesuai dengan ketentuan yang berlaku;

g. Menyerahkan dokumen pengeluaran/pertanggungjawaban kepada bendahara pengeluaran dengan membuat DRPP (Daftar Rincian Permintaan Pembayaran);

h. Menyusun Laporan Pertanggungjawaban (LPJ);

i. Menyusun Rekonsiliasi Keuangan;

j. Menyimpan dan memelihara dokumen pengeluaran anggaran;

k. Melaporkan hasil pelaksanaan tugas kepada atasan sebagai pertanggungjawaban pelaksanaan tugas;

I. Melaksanakan tugas kedinasan lain yang diberikan oleh atasan

5. Administrasi Kepegawaian

Tugas administrasi kepegawaian pada Departemen Konservasi Sumberdaya Hutan dan Ekowisata, yaitu sebagai berikut:

a. Memproses surat ijin cuti pegawai di lingkungan Unit;

b. Menyiapkan dokumen penilaiann kinerja di lingkungan Unit;

c. Memproses usul pembuatan karpeg, karis/karsu, taspen dan askes di lingkungan Unit;

d. Memproses usul pegawai di lingkungan Unit yang akan mengikuti diklat prapurna tugas;

e. Menyusun konsep surat pegawai, memproses surat ijin cerai pegawai;

f. Menata dokumen kepegawaian; 
g. Memproses usul mengikuti diklat prajabatan, diklat teknis, diklat fungsional dan diklat Struktural pegawai;

h. Menyusun konsep pemberian ijin belajar/tugas belajar bagi pegawai;

i. Memproses usul pemberian penghargaan Satyalancana Karyasatya dan penghargaan lain kepada pegawai melaporkan hasil pelaksanaan tugas kepada atasan sebagai pertanggungjawaban;

j. Memproses Dupak, KP4, melaksanakan tugas, menduduki Jabatan;

k. Melaksanakan tugas kedinasan lain yang diberikan atasan

6. Administrasi Pendidikan

Administrasi pendidikan terbagi dua yaitu administrasi pendidikan sarjana (S1) dan pascasarjana (S2\&S3). Tugas Administrasi Pendidikan yaitu sebagai berikut:

a. Membantu layanan registrasi dan heregistrasi sesuai dengan prosedur (S1, S2 dan S3);

b. menyiapkan jadwal perkuliahan, ruang perkuliahan, pengampu, presensi (S1, S2 dan S3);

c. melayani administrasi kartu rencana studi, kartu hasil studi (S1, S2 dan S3);

d. memproses pembuatan surat keterangan, panggilan, pemberitahuan kegiatan pendidikan (S1, S2 dan S3);

e. menyiapkan administrasi perkuliahan, praktikum, seminar, kolokium, sidang komisi dan pertemuan ilmiah (S1, S2 dan S3);

f. menyiapkan administrasi penelitian dan pengabdian masyarakat (S1, S2 dan S3);

g. membantu persiapan kegiatan ujian semester/skripsi/thesis/disertasi (S1, S2 dan S3);

h. menyiapkan administrasi penerbitan ijazah lulusan, transkrip lulusan, wisudawan (S1);

i. mencatat/mengentri data mahasiswa dalam buku induk/database (S1, S2 dan S3);

j. menyiapkan data mahasiswa peserta KKN/KKP/PKL (S1);

k. melayani pendaftaran calon wisudawan (S1);

I. mengelola arsip dan dokumen data pendidikan/akademik sesuai dengan prosedur agar tertib administrasi (S1, S2 dan S3);

m. melaporkan pelaksanaan tugas (S1, S2 dan S3); 
n. melaksanakan tugas lain sesuai perintah atasan (S1, S2 dan S3).

7. Administrasi Sarana dan Prasarana Pendidikan

Tugas administrasi sarana dan prasarana pendidikan yaitu sebagai berikut:

a. memproses surat masuk/surat jawaban usul rencana kebutuhan sarana pendidikan di lingkungan Institut;

b. menyiapkan bahan dan dokumen layanan pendistribusian sarana pendidikan di lingkungan Institut;

c. membantu layanan pendistribusian sarana pendidikan di lingkungan Institut;

d. menyusun kebutuhan alat tulis kantor sesuai dengan ketentuan untuk kelancaran pelaksanaan tugas di lingkungan Institut;

e. menata arsip dan dokumen sarana pendidikan di Institut agar tertib administrasi;

f. melayani peminjaman arsip dan dokumen sarana pendidikan di lingkungan Institut sesuai ketentuan;

g. melaporkan pelaksanaan tugas;

h. melaksanakan tugas lain sesuai perintah atasan.

8. Teknisi Laboran

Tugas dari teknisi laboran pada Departemen Konservasi Sumberdaya Hutan dan Ekowisata, adalah sebagai berikut:

a. merencanakan kebutuhan alat dan bahan yang dibutuhkan untuk kegiatan di laboratorium untuk menjamin ketersediaan alat dan bahan di gudang bahan.

b. mencatat jumlah pemakaian bahan yang dibutuhkan untuk setiap kegiatan yang dilakukan di laboratorium untuk mengetahui jumlah keseluruhan pemakaian bahan sebagai dasar perhitungan untuk stock opname;

c. melakukanstock opname bahan yang masuk dan keluar laboratorium secara berkala untuk memonitor persediaan bahan di gudang;

d. melakukan pemeliharaan dan perawatan rutin terhadap alat-alat laboratorium;

e. membantu menyiapkan bahan dan alat untuk keperluan praktikum dan penelitian mahasiswa dan dosen; 
f. menyiapkan bahan dan alat untuk pengujian sampel;

g. menyimpan dan memelihara alat laboratorium;

h. membuat laporan kerusakan alat laboratorium;

i. membuat laporan hasil kerja kegiatan teknisi laboratorium kepada atasan sebagai pertanggungjawaban pelaksanaan tugas;

j. melaksanakan tugas kedinasan lain yang diberikan oleh atasan.

9. Pustakawan

Tugas pustakawan pada Departemen Konservasi Sumberdaya Hutan dan Ekowisata, adalah sebagai berikut:

a. Melayani dan membantu pengguna untuk mendapatkan informasi dengan cara mengarahkan agar pencarian informasi dapat efisien, efektif, tepat sasaran serta tepat waktu;

b. melakukan pengadaan dan pengolahan bahan pustaka;

c. mengelola buku-buku yang tersedia di perpustakaan dengan benar dan rapi;

d. mengelola dan mencetak barcode buku-buku;

e. mengelola laporan administrasi;

f. mengelola pelayanan peminjaman buku;

g. mengelola keanggotaan pengguna;

h. melaksanakan tugas kedinasan lain yang diberikan oleh atasan.

10. Pramu Kantor

Tugas pramu kantor pada Departemen Konservasi Sumberdaya Hutan dan Ekowisata adalah sebagai berikut:

a. mengusulkan kebutuhan perlengkapan kebersihan termasuki bahan kimia yang diperlukan untuk pembersih lantai, meubeler, kaca dan toilet serta pengharum ruangan;

b. membersihkan ruangan, koridor, toilet, gazebo, lobby dan kaca ruangan serta gedung;

c. memelihara dan merawat tanaman yang ada di dalam ruangan dan luar ruangan;

d. menyusun/merapikan tumpukan barang-barang dan buku-buku yang ada di meja atau di lantai;

e. membersihkan parit/sistem drainase yang ada di sekitar gedung;

f. menyiapkan ruangan/gedung/lapangan untuk kegiatan-kegiatan rapat, wisuda dan kegiatan lain untuk kelancaran pelaksanaannya; 
g. membuka/menutup pitu ruangan/gedung sesuai ketentuan yang berlaku;

h. mengawasi keberadaan meubeler/peralatan/dan barang-barang staf yang terletak dalam ruangan;

i. member dan menyajikan makanan dan minuman untuk para tamu pimpinan/lembaga dan pegawai;

j. melaporkan hasil pelaksanaan tugas kepada atasan sebagai pertanggungjawaban;

k. melaksanakan tugas kedinasan lain yang diberikan atasan.

\subsection{Sumber Daya Manusia}

Jumlah sumber daya manusia (SDM) yang ada pada Departemen Konservasi Sumberdaya Hutan dan Ekowisata (DKSHE) FAHUTAN IPB sampai dengan tahun 2015 yaitu sebanyak 56 orang, yang terdiri dari:

Tabel 3.1

Jumlah SDM pada Departemen KSHE

Sampai dengan Tahun 2015

\begin{tabular}{|c|c|c|c|c|}
\hline No. & $\begin{array}{c}\text { Jenis Tenaga Pendidik dan Tenaga } \\
\text { Kependidikan }\end{array}$ & PNS & honorer & Jumlah \\
\hline 1 & Dosen & 33 & & 33 \\
\hline 2 & Ketua Tata Usaha & 1 & & 1 \\
\hline 3 & BPP & 1 & & 1 \\
\hline 4 & Staf Administrasi Kepegawaian & & 1 & 1 \\
\hline 5 & Staf Administrasi Pendidikan & 5 & 1 & 6 \\
\hline 6 & Staf Administrasi Sarana dan Prasarana & 1 & & 1 \\
\hline 7 & Laboran & 7 & & 7 \\
\hline 8 & Pustakawan & 1 & & 1 \\
\hline 9 & Pramu Kantor & & 4 & 4 \\
\hline 10 & Supir Departemen & & 1 & 1 \\
\hline & Jumlah & 49 & 7 & 56 \\
\hline
\end{tabular}




\subsection{Sarana dan Prasarana}

Departemen Konservasi Sumberdaya Hutan dan Ekowisata (DKSHE) merupakan departemen yang berada di bawah naungan Fakultas Kehutanan IPB. DKSHE memiliki dua gedung yang berbeda yaitu gedung sarjana dan gedung pascasarjana. Namun keduanya berada pada lokasi yang sama, yaitu berlokasi di IPB Dramaga. Dalam kegiatan rutinitasnya, DKSHE menyediakan sarana dan prasarana yang digunakan untuk melaksanakan kegiatan belajar mengajar (KBM), kegiatan dosen, kegiatan mahasiswa, dan kegiatan para staf tenaga kependidikan.

Sarana dan Prasarana yang disediakan untuk kegiatan dosen diantaranya yaitu adanya Ruang Dosen, Ruang Rapat Dosen, dan Ruang Divisi, sedangkan untuk KBM dan kegiatan mahasiswa lainnya DKSHE menyediakan Laptop, Ruang Kuliah, Ruang Diskusi Mahasiswa, Laboratorium dan Ruang Perpustakaan. Semua sarana dan prasarana yang disediakan oleh DKSHE disesuaikan dengan kebutuhan masing-masing pihak.

Ruangan-ruangan yang disediakan oleh DKSHE pun sudah dilengkapi dengan Air Conditioner ( $A C)$, sedangkan untuk ruang kuliah, ruang rapat dan ruang laboratorium tidak hanya dilengkapi dengan AC tetapi dilengkapi juga dengan adanya LCD Proyektor. LCD proyektor biasanya digunakan oleh mahasiswa untuk melaksanakan perkuliahan, melaksanakan sidang komisi ataupun kegiatan lainnya yang berhubungan dengan akademik.

Begitu pula dengan para staf dalam melaksanakan tugas dan fungsinya, DKSHE menyediakan fasilitas berupa ruang kerja untuk masing-masing bagian. Ruang kerja yang disediakan oleh DKSHE untuk bagian administrasi akademik terbagi menjadi dua, yaitu bagian administrasi sarjana dan administrasi pasacasarjana. Kedua ruangan tersebut pun dilengkapi dengan adanya Komputer kerja, Printer, Scanner, Telepon Kantor, Faximile, AC, Lemari berkas, dan lain sebagainya.

\subsection{Uraian Singkat Kegiatan Magang}

Kegiatan magang dilakukan oleh penyusun untuk menyusun Tugas Akhir pada Program Studi Akuntansi STIE Kesatuan. Penyusunan tugas akhir ini dilakukan oleh penyusun untuk menyelesaikan pendidikan DIPLOMA III. Penyusun melaksanakan magang pada sebuah lembaga pendidikan perguruan 
tinggi di Bogor yaitu pada Departemen Konservasi Sumberdaya Hutan dan Ekowisata (DKSHE), Fakultas Kehutanan IPB Dramaga Bogor. Pelaksanaan magang dilakukan oleh penyusun terhitung mulai tanggal 1 April 2015 sampai dengan tanggal 1 Juni 2015, pada jam 08.00 sampai dengan jam 16.00 WIB.

Penyusun merupakan staf administrasi pascasarjana pada Departemen Konservasi Sumberdaya Hutan dan Ekowisata (DKSHE), sehingga pelaksanaan magang dilakukan oleh penyusun pada saat jam kerja. Namun, penyusun tidak melaksanakan magang sepanjang jam kerja. Pelaksanaan magang dilakukan secara bertahap dari hari ke hari dengan jam magang yang tidak menentu. Adapun rincian kegiatan yang dilakukan oleh penyusun selama melaksanakan magang di DKSHE, yaitu sebagai berikut:

1. Tanggal 25 Maret 2015, penyusun meminta ijin kepada Ketua Departemen selaku pimpinan DKSHE untuk melaksanakan magang mengenai pengelolaan dana kas yang ada pada DKSHE.

2. Setelah mendapat persetujuan dari Ketua Departemen, memohon ijin juga kepada Kepala Tata Usaha dan BPP DKSHE.

3. Melakukan wawancara kepada BPP, terkait dengan sistem dan prosedur pembentukan dana kas serta melihat dokumen-dokumen pendukungnya.

4. Melakukan wawancara kepada BPP, terkait dengan sistem dan prosedur penggunaan dana kas serta melihat dokumen-dokumen pendukungnya.

5. Melakukan wawancara kepada BPP, terkait dengan sistem pengendalian dan pengawasan yang diterapkan oleh DKSHE terhadap dana kas yang dimiliki.

6. Melihat arsip-arsip dokumen yang dilakukan oleh BPP terkait dengan dana kas.

Dengan adanya pelaksanaan magang di Departemen Konservasi Sumberdaya Hutan dan Ekowisata (DKSHE), penyusun dapat memperoleh ilmu yang bermanfaat dari dunia kerja yang sebenarnya. Penyusun juga dapat membandingkan antara ilmu teori mengenai pengelolaan dana kas yang diterima pada saat perkuliahan dengan yang dilaksanakan pada dunia kerja sebenarnya. 


\subsection{Perbandingan Teori dan Praktek}

\subsubsection{Sistem dan Prosedur Pembentukan Dana Kas DKSHE}

Awal pembentukan dana kas pada Departemen Konservasi Sumberdaya Hutan dan Ekowisata (DKSHE) yaitu dengan cara mengusulkan pembukaan Rekening Petty Cash. Usulan pembukaan Rekening Petty Cash harus didasari dengan adanya persetujuan Rektor IPB. Dalam hal ini, Rekening Petty Cash merupakan rekening Rektor pada Bank yang dipergunakan untuk menampung dana serta untuk keperluan belanja unit kerja (departemen) dalam rangka pelaksanaan Rencana Kegiatan dan Anggaran Tahunan (RKAT) unit kerja dengan ditandatangani oleh atasan Petty Cash (Pimpinan Unit Kerja) dan Pemegang Petty Cash.

RKAT merupakan rincian dari rencana kegiatan dan anggaran yang akan dilaksanakan oleh departemen selama satu tahun untuk melakukan kegiatan operasionalnya. RKAT dibuat berdasarkan kebutuhan departemen dengan mengasumsikan jumlah besaran yang akan dikeluarkan pada saat tahun berjalan. Jumlah besaran yang dibuat pada RKAT departemen, akan menjadi saldo kas selama satu tahun, sehingga saldo tersebut pun menjadi batasan dana yang dimiliki dan dipergunakan oleh departemen selama satu tahun. Dilihat dari cara pembentukan dana kasnya, metode pencatatan yang dilakukan oleh DKSHE yaitu menggunakan metode fluktuasi, dimana pada metode tersebut jumlah besaran yang dibentuk pada dana kas disesuaikan dengan kebutuhan departemen.

DKSHE mengusulkan pembukaan rekening dengan mengikuti aturan dan ketentuan yang berlaku di IPB, yaitu dengan cara mengirimkan RKAT kepada Rektor. Apabila RKAT yang dikirimkan oleh departemen disetujui oleh Rektor, maka selanjutnya Rektor akan membuatkan surat persetujuan pembukaan rekening petty cash departemen. Surat persetujuan tersebut dikirimkan dari Rektor kepada departemen untuk ditindaklanjuti. Departemen menindaklanjuti surat tersebut dengan cara mengurus administrasi pembukaan rekening petty cash pada bank yang ditunjuk sebagai payroll, yaitu Bank BNI.

Dalam hal ini, rekening yang akan dibuka oleh departemen yaitu berupa rekening giro dan rekening tersebut dibuat atas nama REKTOR IPB CQ. DEPT $\mathrm{KSH}$. Apabila proses pembukaan rekening petty cash departemen sudah selesai, maka tahap selanjutnya yang dilakukan oleh departemen yaitu membuat surat pemberitahuan nomor rekening departemen yang 
ditandatangani oleh ketua departemen selaku pimpinan. Surat yang telah dibuat dan ditandatangani oleh ketua departemen kemudian dikirimkan kepada Direktorat Keuangan (DITKEU) IPB. Nomor rekening yang dikirimkan tersebut akan dipergunakan oleh DITKEU untuk mengirimkan setiap dana yang diajukan oleh departemen dan berdasarkan RKAT yang sudah dibuat.

Sistem dan prosedur yang dilakukan oleh departemen pada saat melakukan pembentukan dana kas yaitu sebagai berikut:

1. Ketua Departemen membuat RKAT departemen sesuai dengan kebutuhan operasional departemen selama satu tahun.

2. RKAT yang telah selesai dibuat, kemudian dicetak sebanyak dua lembar, dimana satu lembar diserahkan kepada Rektor IPB untuk disetujui dan satu lembar diarsipkan oleh Departemen.

3. DKSHE menunggu persetujuan Rektor IPB

4. Setelah RKAT mendapat persetujuan dari Rektor IPB, maka DKSHE akan menerima surat persetujuan dari Rektor IPB untuk ditindaklanjuti pada tahap berikutnya.

5. DKSHE menindaklanjuti surat persetujuan tersebut pada Bank BNI.

6. DKSHE Mengumpulkan dan menyiapkan syarat administrasi yang diperlukan oleh Bank.

7. Bank menerima dan memproses pendaftaran pembukaan rekening petty cash departemen.

8. Setelah proses pendaftaran selesai, maka Bank akan mengeluarkan Rekening Petty Cash.

9. Rekening Petty Cash yang diterima departemen berupa rekening giro.

10. Ketua Departemen membuat surat pemberitahuan kepada Direktorat Keuangan (Ditkeu IPB) mengenai nomor rekening.

Bagan alir terkait dengan mekanisme pembentukan dana kas DKSHE dapat dilihat pada gambar 3.3 sebagai berikut: 


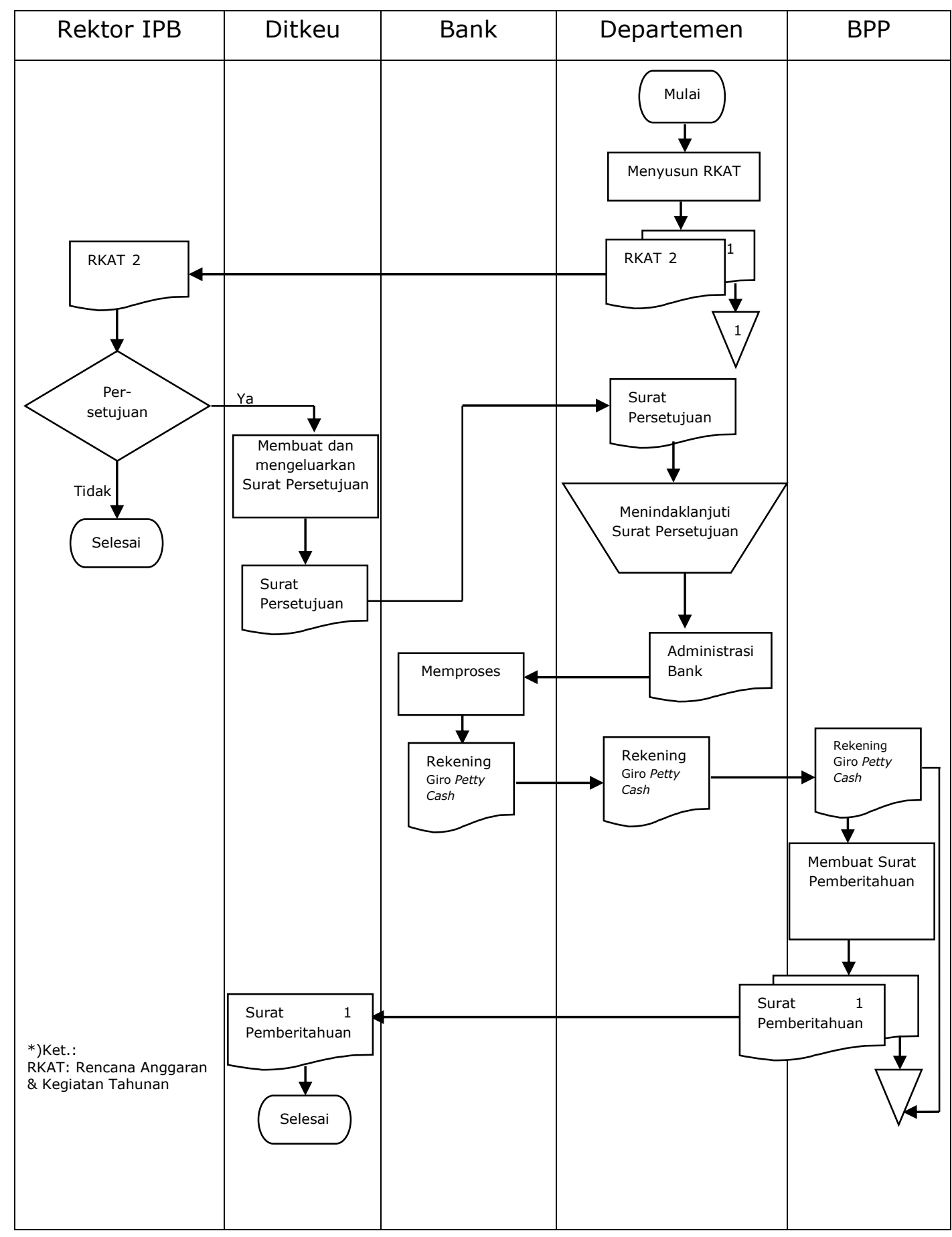

Gambar 3.3

Sistem dan Prosedur Pembentukan Dana Kas DKSHE 


\subsubsection{Sistem dan Prosedur Pengeluaran dan Pencatatan Dana Kas DKSHE}

Dana kas yang ada pada DKSHE dapat digunakan oleh seluruh staf DKSHE, baik staf dosen maupun staf pegawai. Namun, setiap penggunaannya harus berdasarkan anggaran yang sudah dibuat pada RKAT departemen. Penggunaan dana kas DKHSE dapat terjadi secara terencana dan tidak terencana. Pengeluaran terencana biasanya terjadi untuk membayar biaya cetak leaflet program studi, biaya kegiatan lokakarya atau seminar, biaya praktikum mahasiswa, pembelian ATK dalam jumlah besar dan lain sebagainya.

Prosedur yang dilakukan oleh staf pada saat melakukan pengeluaran terencana yaitu dengan mengirimkan surat pengajuan dana terlebih dulu kepada ketua departemen. Surat pengajuan tersebut dikirimkan untuk meminta persetujuan karena hanya ketua departemen yang memiliki wewenang untuk menyetujuinya. Surat yang sudah disetujui oleh ketua departemen, kemudian diserahkan oleh ketua departemen kepada Kepala Tata Usaha (KTU) untuk diketahui. Setelah KTU menerima surat tersebut, maka KTU menyerahkan kepada BPP untuk segera diproses.

Bendahara Pengeluaran Pembantu (BPP) memproses pengajuan dana sesuai dengan jumlah yang diajukan dan membuatkan kuitansi pembayaran. Kuitansi pembayaran yang dibuat oleh BPP yaitu sebanyak dua rangkap untuk ditandatangani oleh staf yang menerima uang. Jika kuitansi sudah ditandatangani, maka kedua rangkap kuitansi tersebut diarsipkan dan BPP tidak menyerahkan satu kuitansi pembayaran kepada staf. Staf hanya memperoleh dana yang diajukan.

Berbeda halnya dengan pengeluaran yang tidak terencana, pengeluaran tidak terencana biasanya terjadi untuk membiayai jamuan rapat rabuan (rapat yang dilaksanakan setiap hari rabu dan dihadiri oleh Staf Dosen KSHE), pembelian tinta printer, pembelian air galon, biaya fotocopy, dan lain sebagainya. Pada pengeluaran yang tidak terencana biasanya terjadi tanpa mengirimkan surat pengajuan terlebih dulu kepada ketua departemen. Staf hanya melakukan pengajuan lisan secara langsung kepada BPP. Namun, BPP tidak begitu saja memproses pengajuan, tetapi BPP meminta persetujuan KTU terlebih dulu. Dalam hal ini, KTU merupakan pihak yang diberikan kewenangan oleh ketua departemen untuk mengotorisasi pengeluaran yang terjadi secara tidak terencana dengan batas maksimum dana yang diajukan 
sebesar Rp 1juta. Jika KTU sudah menyetujui maka BPP memproses pengajuan tersebut, dan membuatkan kuitansi sementara. Kuitansi sementara dibuat oleh BPP hanya satu rangkap, untuk ditandatangani oleh staf penerima uang. Apabila kuitansi sementara sudah ditandatangani oleh staf maka kuitansi tersebut diarsipkan oleh BPP. Jumlah yang tertera pada kuitansi sementara yaitu sebesar jumlah uang yang diberikan oleh BPP kepada staf. Jumlah tersebut dapat lebih besar atau lebih dari yang seharusnya terjadi pada saat transaksi.

Sebagai bentuk pertanggungjawaban, staf yang melakukan transaksi harus menyerahkan bukti atau nota transaksi kepada BPP. Bukti atau nota transaksi yang diterima oleh BPP, kemudian di cek oleh BPP mengenai jumlah besaran yang terjadi. Jika dana yang diberikan oleh BPP masih tersisa, maka staf menyerahkan sisa tersebut kepada BPP, sedangkan jika dana yang diberikan oleh BPP kurang dari yang seharusnya maka staf akan memperoleh penggantian dana.

Prosedur selanjutnya yang dilakukan oleh BPP jika transaksi pada pengeluaran tidak terencana sudah selesai, maka BPP membuatkan kuitansi pembayaran sebanyak dua rangkap. Jumlah besaran yang tertera pada kuitansi pembayaran adalah sebesar jumlah yang tertera pada bukti atau nota transaksi. Kedua kuitansi tersebut ditandatangani oleh staf, dan kedua kuitansi tersebut diarsipkan oleh BPP. Namun, seperti halnya pada pengeluaran terencana, staf yang melakukan transaksi tidak memperoleh kuitansi pembayaran dari BPP.

Meskipun DKSHE menggunakan metode fluktuasi, namun dalam kenyataannya metode pencatatan yang dilakukan DKSHE berbeda dengan yang seharusnya pada catatan akuntansi, karena setiap terjadinya pengeluaran BPP tidak melakukan jurnal. BPP melakukan pencatatan sesuai dengan tanggal pengeluaran yang terjadi pada Kas Tunai Manual berupa file excel di komputer kerja BPP dan mengisi aplikasi SIMKEU IPB. Selain itu, BPP hanya membuat salinan file berupa print out.

Selain dari pencatatannya yang tidak sesuai dengan metode fluktuasi berdasarkan catatan akuntansi, terdapat juga kelemahan dalam penyalinan dokumen yang dilakukan. Kelemahan tersebut contohnya, yaitu ketika departemen sedang mengalami pemadaman listrik, komputer kerja mendadak rusak atau sinyal internet kurang baik, maka BPP tidak dapat melakukan pencatatan pengeluaran yang terjadi pada hari tersebut, karena BPP hanya bergantung dengan ketersediaan internet dan komputer kerja. 
Selain itu, setiap terjadinya pengeluaran, baik yang terencana maupun tidak terencana, DKSHE tidak menerapkan adanya prosedur pengisian formulir pengajuan dana. Sehingga BPP baru mempersiapkan dana setelah mendapat persetujuan dari ketua departemen dan KTU.

Contoh ilustrasi:

Bunga melakukan pengajuan dana kepada BPP secara tidak terencana. Pengajuan dana yang dilakukan oleh BPP yaitu untuk pembelian ATK. BPP menyerahkan dana kepada Bunga sebesar Rp 300.000 dan membuatkan satu kuitansi sementara seperti pada lampiran 7. Kuitansi sementara tersebut untuk ditandatangani oleh bunga dan diarsipkan oleh BPP, kemudian dicatat pada kas tunai manual sesuai dengan jumlah yang dikeluarkan.

Setelah Bunga selesai melakukan transaksi, maka Bunga harus menyerahkan nota atau bukti transaksi kepada BPP sebagai bentuk pertanggungjawaban atas dana yang digunakan, dan BPP mengecek jumlah yang tertera pada nota. Jika jumlah yang dikeluarkan BPP lebih besar, maka Bunga harus menyerahkan dana yang tersisa, tetapi jika jumlah yang dikeluarkan BPP lebih maka BPP mengganti selisih jumlah dana tersebut.

Prosedur selanjutnya yang dilakukan oleh BPP yaitu membuat dua rangkap kuitansi pembayaran senilai jumlah yang tertera pada nota transaksi, kemudian ditandatangani kembali oleh Bunga. Setelah ditandatangani, kedua kuitansi tersebut diarsipkan denga melampirkan nota transaksi. Kemudian BPP mencatat pengeluaran tersebut pada Aplikasi SIMKEU IPB.

Berdasarkan contoh ilustrasi di atas, maka dapat dilihat bahwa sistem dan prosedur penggunaan dana kas DKSHE terdapat kelemahan dari segi arus dokumen, yaitu Bunga tidak memperoleh kuitansi pembayaran ataupun kuitansi sementara dari BPP. Bunga hanya mendapat sejumlah dana yang diperlukan untuk melakukan transaksi. Sehingga pada DKSHE belum adanya transparansi atara BPP dan staf yang menerima dana. 
Sistem dan Prosedur yang dilakukan DKSHE pada pengeluaran yang terencana pada DKSHEyaitu sebagai berikut:

1. Staf (Dosen ataupun pegawai) membuat surat pengajuan dana sebanyak dua lembar.

2. Satu lembar untuk diarsipkan oleh staf dan satu lembar dikirimkan kepada Ketua Departemen KSHE untuk diketahui dan disetujui.

3. Surat yang sudah diketahui dan disetujui oleh Ketua Departemen, maka selanjutnya surat tersebut diserahkan ke Kepala Tata Usaha (KTU) untuk diketahui.

4. KTU kemudian menyerahkan surat yang disetujui Ketua Departemen kepada BPP.

5. BPP memproses pengajuan yang sudah disetujui tersebut.

6. BPP mencatat pengeluaran Kas Tunai Manual berupa file excel pada komputer kerja BPP dan membuat salinan file.

7. BPP mengisi aplikasi yang disediakan oleh IPB yaitu SIMKEU; dimana SIMKEU tersebut akan secara otomatis mengisi Buku Kas Tunai (BKT), Buku Kas Umum (BKU) dan Buku Pajak.

8. BPP mengeluarkan dana dari kas BPP sebesar yang diajukan dan membuatkan dua rangkapkuitansi pembayaran untuk ditandatangani oleh staf penerima uang.

9. Dua rangkap kuitansi yang sudah ditandatangani, kemudian diarsipkan oleh BPP dan dilampirkan dengan surat pengajuan yang sudah disetujui oleh ketua departemen.

10. Staf melakukan transaksi dengan pihak ketiga

11. Setelah transaksi selesai, staf menyerahkan nota pembelian kepada BPP sebagai bentuk pertanggungjawaban atas dana yang digunakan.

12. Nota pembelian/rincian pengeluaran kemudian diarsipkan oleh BPP bersama dengan surat pengajuan dan kuitansi pembayaran sebagai Surat Pertanggungjawaban (SPJ) BPP.

Bagan alir terkait dengan sistem dan prosedur pada pengeluaran yang terencana dapat dilihat pada gambar 3.4 sebagai berikut: 


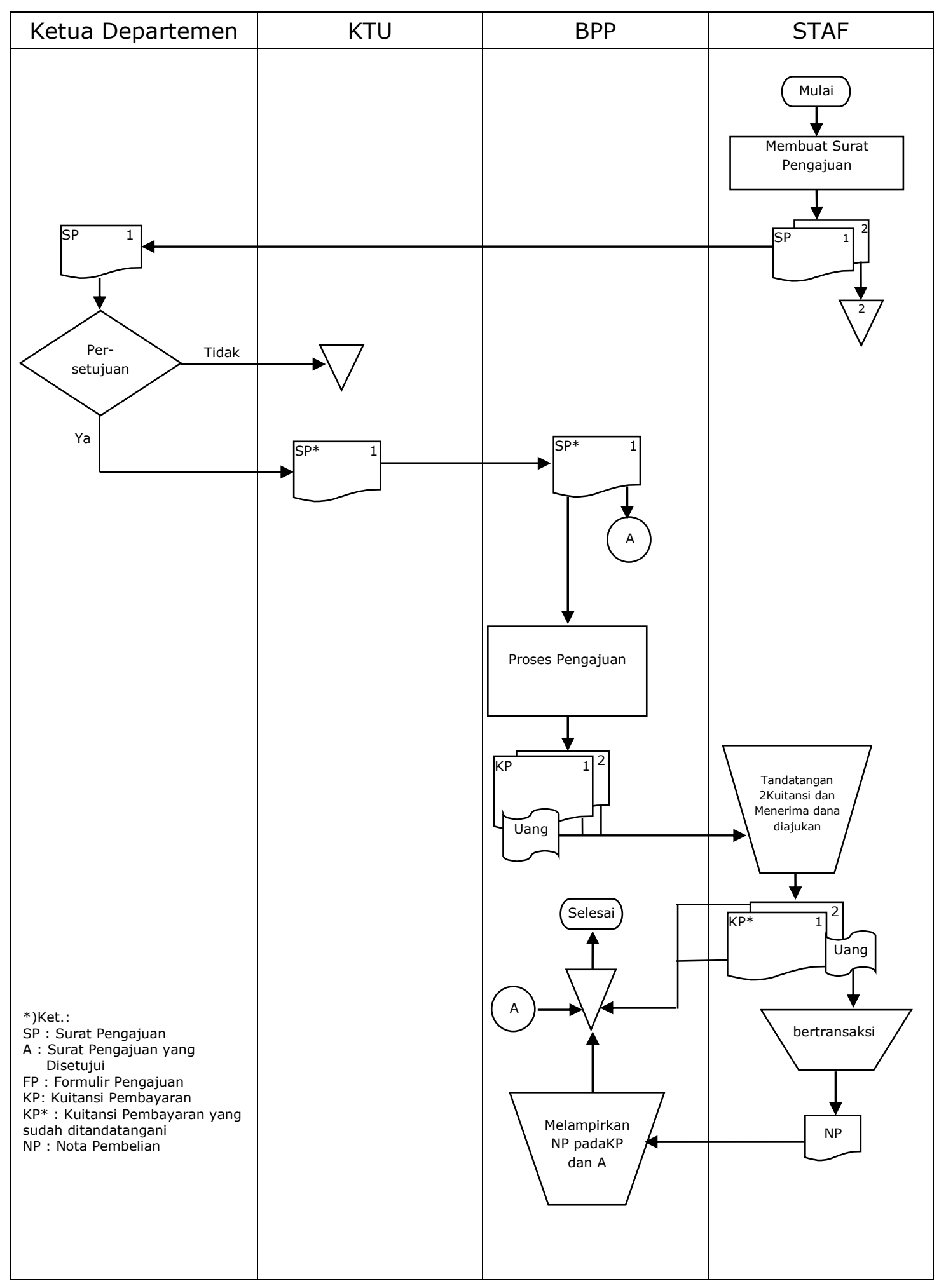

Gambar 3.4

Sistem dan Prosedur Pengeluaran Dana Kas yang Terencana pada DKSHE 
Sedangkan alur dari mekanisme yang dilakukan ketika terjadi pengeluaran yang tidak terencana pada DKSHE yaitu sebagai berikut:

1. Staf (dosen atau pegawai) mengajukan pengeluaran kepada BPP secara lisan.

2. BPP meminta persetujuan KTU terlebih dulu.

3. Apabila KTU menyetujui maka BPP mengeluarkan uang dari kas BPP sesuai jumlah yang diajukan oleh staf untuk melakukan transaksi. Namun, jka tidak disetujui, maka BPP tidak memproses pengajuan tersebut.

4. BPP mencatat dalam Kas Tunai Manual (KTM) pada file excel berdasarkan tanggal pengeluaran dana kas.

5. BPP membuatkan satu rangkap kuitansi sementara, kemudian kuitansi tersebut ditandatangani oleh staf yang menerima uang.

6. Kuitansi sementara yang sudah ditandatangani, kemudian diarsipkan oleh BPP.

7. Staf melakukan transaksi dengan pihak ketiga.

8. Setelah selesai melakukan transaksi, maka staf harus memberikan bukti atau nota transaksi yang ditandatangani atau di cap oleh pihak ketiga.

9. BPP menerima bukti atau nota transaksi

10. BPP mengecek jumlah biaya yang terpakai oleh staf.

11. Apabila jumlah biaya yang dikeluarkan lebih besar dari perkiraan maka staf menerima penggantian uang dari BPP, akan tetapi jika jumlah perkiraan lebih besar dari biaya yang dikeluarkan maka staf harus mengembalikan sisa uang tersebut kepada BPP.

12. Jika ada perubahan nilai nominal pada transaksi, maka BPP mengganti jumlah yang sudah tercatat pada Kas Tunai Manual sesuai dengan jumlah yang sebenarnya terjadi.

13. BPP membuatkan kuitansi pembayaran sebanyak dua rangkap sesuai dengan jumlah yang tertera pada nota transaksi.

14. Staf menandatangani dua rangkap kuitansi pembayaran.

15. BPP mengarsipkan kedua rangkap kuitansi pembayaran yang sudah ditandatangani oleh staf, dan melampirkan notatransaksi.

16. Kuitansi pembayaran beserta nota transaksi tersebut kemudian disimpan oleh BPP dalam folder khusus.

17. BPP mencatat pengeluaran dengan mengisi aplikasi yang disediakan oleh IPB yaitu SIMKEU, dimana SIMKEU tersebut secara otomatis akan mengisi Buku Kas Tunai, BKU dan Buku Pajak. 
Bagan alir sistem dan prosedur pengeluaran yang tidak terencana pada DKSHE dapat dilihat pada gambar berikut ini:

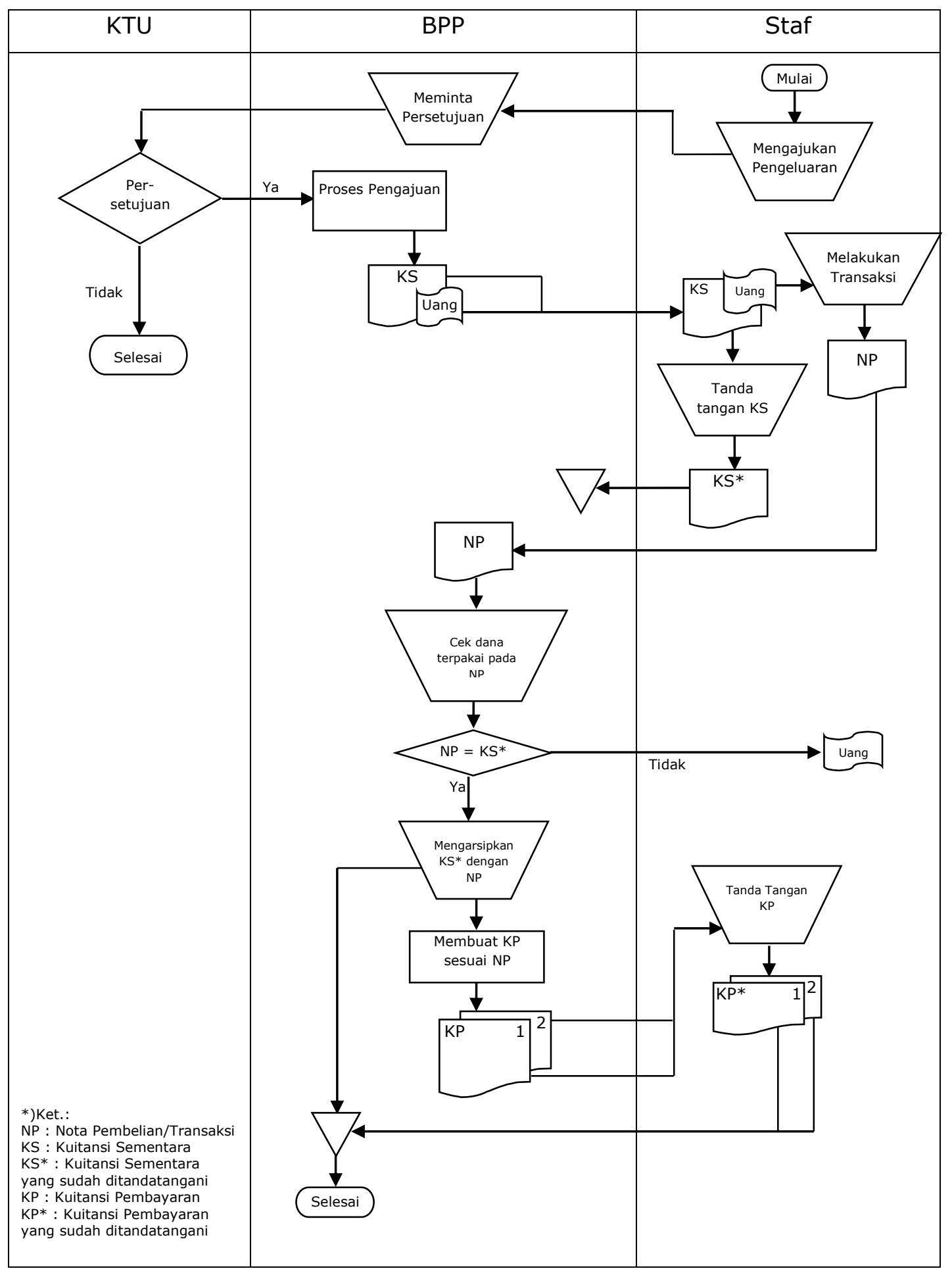

Gambar 3.5

Sistem dan Prosedur Pengeluaran Dana Kas Tidak Terencana pada DKSHE 


\subsubsection{Sistem dan Prosedur Pengisian Kembali Dana Kas DKSHE}

DKSHE melakukan pengisian kembali dana kas apabila saldo yang tersedia pada rekening petty cash sudah mencapai batas minimum. Prosedur yang dilakukan oleh DKSHE saat melakukan pengisian dana kas yaitu dengan menggunakan dokumen berupa Surat Permintaan Pembayaran Dana Masyarakat (SPM-DM) dan Surat Permintaan Membayar (SPM-DM). Format SPP-DM dan SPM-DM harus berdasarkan aturan dan ketentuan yang berlaku di IPB.

SPP-DM merupakan surat pengajuan dana yang dibuat oleh departemen dan ditandatangani oleh ketua departemen sebagai pembuat komitmen pengajuan dana. Jumlah besaran yang tertera pada SPP-DM disesuaikan dengan kebutuhan departemen selama beberapa periode. SPP-DM dikirimkan kepada Fakultas terlebih dulu untuk kemudian dibuatkan Surat Permintaan Membayar Dana Masyarakat (SPM-DM). Fakultas membuatkan SPM-DM sesuai dengan besaran jumlah yang diajukan oleh departemen pada SPP-DM. Pihak yang menandatangani SPM-DM yaitu Dekan atau wakil dekan fakultas.Apabila SPM-DM sudah selesai dibuatkan oleh fakultas, maka SPMDM tersebut dikirimkan kepada departemen dengan melampirkan kembali SPP-DM.

SPP-DM dan SPM-DM yang diterima oleh departemen, kemudian dikirimkan kepada DITKEU IPB dengan melampirkan Surat pertanggungajawaban (SPJ) atau bukti-bukti pengeluaran yang terjadi pada periode sebelumnya. Apabila dokumen SPP-DM dan SPM-DM sudah diterima oleh DITKEU, maka DITKEU akan memproses pengajuan dana tersebut. DITKEU akan mengeluarkan Surat Perintah Pencairan Dana Masyarakat (SP2DM) sebanyak lima rangkap dengan lembaran warna yang berbeda. Lembar putih dikirimkan oleh DITKEU kepada Bank, lembar merah kepada Subdit Pembendaharaan, lembar kuning kepada Kuasa Pengguna Anggaran, Lembar Biru kepada Pembuat komitmen, dan lembar hijau kepada Subdit. Akuntansi dan Pengendalian Anggaran. Dari kelima lembaran tersebut, SP2DM yang akan diterima oleh DKSHE yaitu lembar SP2DM yang berwarna biru.

Jika DITKEU sudah mengeluarkan SP2DM, maka saldo rekening petty cash departemen akan bertambah sebesar yang diajukan pada SPP-DM dan SPM-DM. BPP dapat mengecek saldo yang diterima tersebut pada website BNI Direct. Website BNI Direct tersebut hanya dapat diakses oleh BPP dan bersifat 
rahasia, sehingga tidak semua staf pegawai DKSHE dapat mengaksesnya. Setelah dana yang diajukan masuk ke dalam saldo rekening, maka prosedur selanjutnya yang dilakukan oleh BPP yaitu melakukan pencairan dana. Pencairan dana ini hanya dapat dilakukan oleh BPP dan tidak dapat diwakilkan oleh staf pegawai lainnya. Pencairan dana dilakukan dengan menggunakan cek, dan cek yang digunakan pun hanya dapat ditandatangani oleh ketua departemen. Sehingga ketua departemen dapat mengetahui setiap pengeluaran ataupun pencairan dana yang terjadi, dan dikeluarkan dari rekening petty cash departemen.

Prosedur yang dilakukan oleh DKSHE dalam mengajukan pengisian kembali dana kas sesuai dengan teori yang ada, yaitu adanya persetujuan dari pihak yang berwenang. Untuk memperoleh persetujuan tersebut, DKSHE mengikuti aturan dan ketentuan yang berlaku di IPB. Selain itu, DKSHE dalam mengajukan dana kas ini pun sesuai dengan teori fluktuasi, yaitu saldo yang diajukan disesuaikan dengan kebutuhan departemen selama beberapa periode.

Adapun alur dari mekanisme pengisian kembali dana kas yang dilakukan oleh DKSHE, yaitu sebagai berikut:

1. DKSHE membuatkan Surat Permintaan Pembayaran (SPP-DM).

2. Ketua DKSHE menandatangani Surat Permintaan Pembayaran (SPPDM).

3. SPP-DM yang sudah selesai dibuat oleh departemen kemudian dikirimkan kepada Fakultas Kehutanan.

4. Fakultas membuatkan Surat Permintaan Membayar (SPM-DM).

5. Dekan/Wakil Dekan Fakultas Kehutanan menandatangani Surat Permintaan Membayar (SPM-DM).

6. SPM-DM yang sudah ditandatangani oleh Dekan/Wakil Dekan kemudian dikirimkan kembali kepada Departemen KSHE dengan melampirkan kembali SPP-DM.

7. DKSHE menerima SPP-DM dan SPM-DM dari Dekan/Wakil Dekan Fakultas Kehutanan

8. Departemen mengirimkan SPP-DM dan SPM-DM kepada Direktorat Keuangan (Ditkeu) dengan melampirkan bukti-bukti/kuitansi pengeluaranpada periode sebelumnya.

9. Direktorat Keuangan (Ditkeu) memverifikasi SPM-DM dan SPP-DMyang diterima dari Departemen. 
10. Setelah melakukan verifikasi, Ditkeu mengeluarkan Surat Perintah Pencairan Dana Masyarakat (SP2DM) sebanyak lima rangkap yang terdiri dari lembar putih, lembar merah, lembar kuning, lembar biru dan lembar hijau.

11. Lembar Biru SP2DM diterima oleh departemen.

12. Jika Ditkeu sudah mengeluarkan Surat Perintah Pencairan Dana Masyarakat (SP2DM), maka saldo rekening petty cash bertambah sesuai jumlah yang diajukan pada SPP-DM dan SPM-DM.

13. BPP mengecek saldo yang masuk pada BNI Direct

14. Jika saldo sudah masuk maka BPP mengajukan sejumlah dana kepada Ketua Departemen untuk melakukan tarik tunai.

15. BPP membuatkan cek sebesar jumlah yang diperlukan selama periode tertentu.

16. Ketua Departemen menandatangani cek yang akan digunakan untuk mencairkan dana.

17. BPP memproses pencairan dana pada Bank.

18. Uang yang sudah dicairkan dari cek, kemudian disimpan pada brangkas departemen.

Bagan alir mekanisme yang dilakukan oleh DKSHE pada saat melakukan pengisian kembali dana kas departemen, yaitu sebagai berikut: 


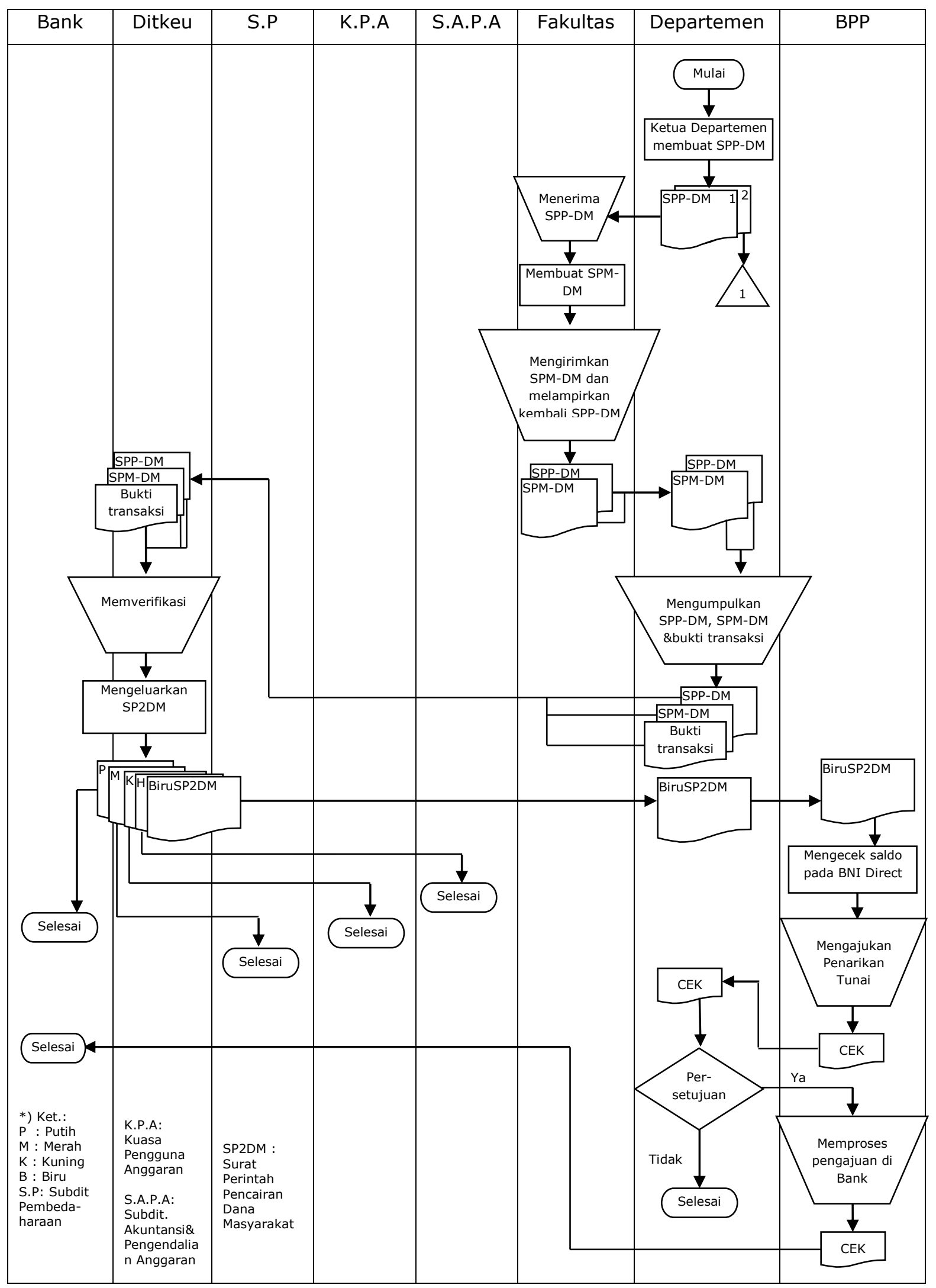

Gambar 3.6

Sistem dan Prosedur Pengisian Kembali Dana Kas DKSHE 


\subsubsection{Sistem Pengendalian dan Pengawasan Dana Kas DKSHE}

Dalam mengelola dana kas yang dimiliki, Departemen Konservasi Sumberdaya Hutan dan Ekowisata (DKSHE) menerapkan adanya sistem pengendalian dan pengawasan. Sistem pengendalian dan pengawasan yang diterapkan oleh DKSHE terhadap dana kas yaitu sebagai berikut:

1. Adanya otorisasi pihak yang berwenang

Pihak yang memiliki wewenang untuk mengotorisasi setiap penggunaan dana kas yaitu ketua departemen dan KTU. Dalam hal ini, Ketua departemen memiliki wewenang untuk menandatangani cek pencairan dana dan memberikan persetujuan pada pengeluaran yang terencana. Berbeda halnya dengan KTU, KTU hanya diberikan kewenangan oleh ketua departemen untuk memberikan persetujuan pada pengeluaran yang tidak terencana dengan batas maksimum dana yang diajukan yaitu sebesar Rp 1juta.

2. Adanya batasan maksimum dan minimum dana pada brangkas

Departemen Konservasi Sumberdaya Hutan dan Ekowisata (DKSHE) menerapkan adanya batas maksimum dan minimum dana yang tersedia di brangkas. Batas maksimum yang diterapkan oleh DKSHE yaitu sebesar Rp 50juta, sedangkan batas minimumnya adalah sebesar Rp 1juta. Namun, dalam kenyataannya BPP tidak pernah menyimpan dana sebesar batas maksimum yang diterapkan karena untuk menghindari terjadinya kehilangan ataupun penyalahgunaan oleh pihak dalam ataupun luar departemen.

3. Hanya BPP yang dapat mengakses keuangan departemen

Username dan password BNI Direct hanya dapat diakses oleh BPP, sehingga tidak semua staf pegawai DKSHE dapat mengakses website tersebut. Selain itu, password pada brangkas pun hanya diketahui oleh BPP saja.

4. Cek pencairan dana dari rekening departemen hanya dapat dipergunakan oleh BPP dan ditandatangani oleh ketua departemen.

Dengan adanya penerapan sistem pengendalian dan pengawasan yang dilakukan oleh DKSHE, dapat meminimalisir terjadinya penyalahgunaan ataupun penyelewengan yang dilakukan oleh karyawan terhadap dana kas yang dimiliki oleh DKSHE. 


\subsubsection{Bagian yang Terkait dengan Pengelolaan Dana Kas DKSHE}

Bagian yang terkait pada pengelolaan dana kas DKSHE yaitu Ketua Departemen, Kepala Tata Usaha (KTU), Bendahara Pengeluaran Pembantu (BPP) dan Staf, baik dosen maupun tenaga kependidikan. Dalam hal ini, Ketua Departemen sangat memiliki peranan penting bagi kelancaran kegiatan operasional, mulai dari BPP melakukan penarikan tunai di bank, melakukan pengeluaran kas, sampai dengan pengisian kembali. Hanya Ketua Departemen yang memiliki wewenang dan kebijakan untuk memberikan keputusan atau menandatangani persetujuan atas kegiatan-kegiatan tersebut. Sehingga, apabila ketua departemen sedang berhalangan untuk berada di tempat, maka staf kegiatan operasional departemen akan terhambat kelancarannya.

Berbeda halnya dengan KTU, KTU hanya memiliki kewenangan untuk memberikan persetujuan kepada BPP dalam memproses pengeluaran yang tidak terencana apabila besaran jumlah yang diajukan kurang dari Rp 1juta. Akan tetapi, jika KTU sedang berhalangan untuk berada di tempat, maka BPP meminta persetujuan secara langsung kepada ketua departemen, sehingga kegiatan operasional yang dilakukan masih dapat berjalan dengan baik.

BPP DKSHE yang mengelola dana kas departemen, hanya dilakukan sendiri mulai dari pembentukan dana kas, memproses pengeluaranpengeluaran yang terjadi, melakukan pencatatan pengeluaran, penyimpanan uang dan dokumen keuangan, penyampaian dokumen ke DITKEU, membuat kuitansi-kuitansi pembayaran atau kuitansi sementara, serta melakukan penarikan tunai di bank. Sehingga BPP DKSHE sangat bertanggungjawab penuh atas dana kas yang dimiliki oleh departemen.

Ketersediaan satu orang BPP yang ada pada DKSHE disesuaikan dengan kebutuhan departemen, karena lingkup keuangan yang dikelola oleh departemen tidak begitu besar. Oleh karena itu, dengan adanya satu orang BPP dianggap sudah cukup untuk menangani dana kas yang dimiliki oleh departemen. Hanya saja, jika dilihat berdasarkan teori, apabila tidak ada pemisahan tugas dan tanggungjawab antara bagian satu dengan bagian lainnya dapat mengakibatkan terjadinya penyalahgunaan ataupun penyelewengan dana kas oleh karyawan.

Bagian-bagian lain yang terkait dengan kas yaitu para staf departemen, baik staf pegawai ataupun staf dosen. Staf memiliki hak untuk mengajukan permohonan dana dalam melakukan kegiatan operasional departemen. 
Namun, pengajuan tersebut harus berdasarkan dengan RKAT yang sudah dibuat oleh departemen. Selain itu, staf juga harus bertanggungjawab atas dana yang diterima secara tunai dari BPP. Pertanggungjawaban tersebut yaitu dengan cara menyerahkan bukti-bukti transaksi yang riil kepada BPP. Sehingga BPP memiliki pelaporan yang dapat dipertanggungjawabkan kepada DITKEU IPB. Secara umum, bagian-bagian yang terkait dalam pengelolaan dana kas DKSHE memiliki tugas dan fungsinya masing-masing. Sehingga pengelolaan dana kas yang ada pada DKSHE sudah berjalan dengan cukup baik.

\subsubsection{Dokumen yang terkait dengan Dana Kas DKSHE}

Dokumen yang biasa digunakan DKSHE terkait dengan dana kas yang dimiliki yaitu Rencana Kegiatan dan Anggaran Tahunan (RKAT), Surat Perintah Pembayaran Dana Masyarakat (SPP-DM), Surat Perintah Membayar Dana Masyarakat (SPM-DM), Surat Perintah Pencairan Dana Masyarakat (SP2DM), bukti pengeluaran dana kas, kuitansi pembayaran, kuitansi sementara dan Cek. RKAT merupakan rencana kegiatan dan anggaran yang dibuat oleh departemen pada awal tahun berjalan. Departemen menyusun RKAT dengan menyesuaikan kebutuhan atau kegiatan yang akan dipenuhi pada tahun tersebut. Jumlah besaran yang tertera pada RKAT adalah batasan saldo yang akan diterima departemen dari rekening Rektor IPB selama satu tahun.

Dokumen yang digunakan departemen saat melakukan pengisian dana kas adalah SPP-DM dan SPM-DM. SPP-DM dibuat oleh departemen dan dikirimkan kepada Fakultas, kemudian Dekan/Wakil Dekan fakultas membuatkan SPM-DM yang dikirimkan kembali ke departemen, untuk kemudian departemen kirimkan ke DITKEU dengan melampirkan Surat pertanggungajawaban (SPJ) atau bukti-bukti pengeluaran yang terjadi pada periode sebelumnya. Setelah SPP-DM dan SPM-DM diterima oleh Ditkeu maka Ditkeu akan mengeluarkan SP2DM. Apabila SP2DM sudah dikeluarkan dan diterima oleh BPP maka saldo rekening petty cashakan bertambah sebesar yang diajukan. BPP dapat mencairkan dana dengan menggunakan Cek. Cek merupakan dokumen yang disiapkan oleh BPP dengan mencantumkan jumlah besaran dana yang akan dicairkan di bank dan hanya dapat ditandatangani oleh ketua departemen. 
Setiap Bendahara Pengeluaran Pembantu (BPP) melakukan pengeluaran, maka dokumen yang digunakan oleh BPP yaitu kuitansi pembayaran dan kuitansi sementara. Kuitansi pembayaran diberikan apabila pengeluaran yang terjadi sudah dilengkapi rincian pengeluaran ataupun nota transaksi, sedangkan kuitansi sementara biasanya dibuat untuk pengeluaran yang tidak terencana dan akan dibuatkan menjadi kuitansi pembayaran apabila transaksi sudah selesai dengan menyerahkan nota transaksi sebagai bentuk pertanggungjawaban. Kuitansi pembayaran yang dibuat oleh BPP hanya sebanyak dua rangkap, dimana keduanya disimpan oleh BPP. Berbeda halnya dengan kuitansi sementara, kuitansi tersebut hanya dibuat satu lembar dan disimpan juga oleh BPP sehingga staf penerima uang hanya menerima uang tanpa kuitansi.

Berdasarkan dari dokumen-dokumen yang sudah digunakan oleh DKSHE, masih terdapat kelemahan jika dilihat secara teori yang ada. Kelemahan tersebut yaitu, BPP tidak menyediakan formulir pengajuan dana kas. Padahal seharusnya formulir tersebut dapat digunakan oleh BPP untuk diisi oleh staf yang mengajukan dana, baik dalam pengajuan dana yang terencana ataupun tidak terencana. Dengan adanya formulir pengajuan dana tersebut dapat membantu BPP untuk menyiapkan dana yang diperlukan sebelum pengajuan yang dilakukan oleh staf disetujui oleh pihak yang berwenang. 



\section{BAB IV \\ SIMPULAN DAN SARAN}

\subsection{Kesimpulan}

Kesimpulan yang dapat ditarik oleh penyusun yaitu sebagai berikut:

1. Sistem dan prosedur pembentukan, pencatatan, penggunaan dan pengajuan dana kas DKSHE yaitu sebagai berikut:

a. Pembentukan dana kas pada Departemen Konservasi Sumberdaya Hutan dan Ekowisata (DKSHE) mengikuti aturan dan ketentuan yang berlaku di IPB, yaitu dengan mengajukan Rencana Kegiatan dan Anggaran Tahunan (RKAT) sebesar jumlah yang dibutuhkan

b. Pencatatan yang dilakukan oleh Bendahara Pengeluaran Pembantu (BPP) DKSHE hanya berupa Kas Tunai Manual dan pengisian Sistem Informasi Keuangan (SIMKEU) IPB

c. Terdapat kelemahan dari segi arus dokumen dalam penggunaan dana kas pada DKSHE

d. Pengisian dana kas pada DKSHE dilakukan pada saat sudah mencapai batas minimum dengan mengikuti sistem dan prosedur yang berlaku di IPB

2. Sistem Pengendalian dan Pengawasan Dana Kas Departemen Konservasi Sumberdaya Hutan dan Ekowisata (DKSHE) dinilai sudah cukup baik, karena terdapat adanya otorisasi pihak yang berwenang, serta adanya penetapan batas maksimum dan minimum dana yang tersedia di brangkas.

3. Secara umum, pengelolaan dana kas Departemen Konservasi Sumberdaya Hutan dan Ekowisata (DKSHE) dinilai sudah cukup baik dan sesuai dengan teori yang ada. Namun masih terdapat kelemahan yaitu tidak adanya pemisahan tugas dan tanggung jawab antara bagian yang melakukan pencatatan pengeluaran dana, penggunaan dana, pengarsipan dokumen yang terkait dengan dana kas, serta pengajuan kembali dana kas. Sehingga hal tersebut pun dapat beresiko terjadinya penyalahgunaan atau penyelewengan yang dilakukan oleh karyawan. 


\subsection{Saran}

Saran yang dapat diberikan oleh penyusun yaitu sebagai berikut:

1. Bendahara Pengeluaran Pembantu (BPP) Departemen Konservasi Sumberdaya Hutan dan Ekowisata (DKSHE) sebaiknya melakukan penyalinan dokumen pada harddisk, flashdisk ataupun pada aplikasi dropbox, karena dengan melakukan penyalinan dokumen pada media lain, dapat membantu BPP jika terjadi kendala pada komputer kerja.

2. Adanya perbaikan dari segi arus dokumen pada penggunaan dana kas Departemen Konservasi Sumberdaya Hutan dan Ekowisata (DKSHE) seperti pada lampiran 10 dan lampiran 11.

3. Sebaiknya terdapat pemisahan tugas dan tanggung jawab dalam pengelolaan dana kas departemen, baik dalam penyimpanan dana, pencatatan, penyimpanan dokumen sampai dengan pengisian kembali dana kas. Dengan adanya pemisahan tugas dan tanggung jawab tersebut, dapat meminimalisir terjadinya penyalahgunaan yang dilakukan oleh karyawan terhadap harta perusahaan ataupun memalsukan catatan akuntansi. Dengan demikian, diharapkan pengelolaan dana kas Departemen Konservasi Sumberdaya Hutan dan Ekowisata (DKSHE) dapat lebih baik bukan hanya untuk saat ini, tapi hingga masa yang akan datang. 


\section{DAFTAR PUSTAKA}

Abubakar Arif dan Wibowo. 2004. Akuntansi Untuk Bisnis Usaha dan Menengah. Grasindo, Jakarta

Adikesavan, T.A., 2014. Management Information Systems: Best Practise and Applications in Business. $2^{\text {nd }}$ Edition. PHI Learning Private Limited, Delhi.

Alfian Malik. 2010. Pengantar Bisnis Jasa Pelaksana Konstruksi. Penerbit Andi, Yogyakarta.

Anastasia Diana dan Lilis Setiawati. 2011. Sistem Informasi Akuntansi Perancangan, Proses, dan Penerapan. Penerbit Andi, Yogyakarta.

Arief Sugiono, Yanuar Nanok Soenarno, Synthia Madya Kusumawati. 2010. Akuntansi \& Pelaporan Keuangan untuk Bisnis Skala dan Menengah. Grasindo, Jakarta

en.wikipedia.org/wiki/Procedure

Hall, James A. 2007. Sistem Informasi Akuntansi. Edisi 4, Buku 1. Salemba 4, Jakarta.

Hanif Al Fatta. 2007. Analisis dan Perancangan Sistem Informasi untuk Keunggulan Bersaing. Penerbit Andi, Yogyakarta.

Harrison, Walter T., Charles T. Horngren, C. William Thomas, Themin Suwardy. 2012. Akuntansi Keuangan Edisi IFRS. Jilid 1. Penerbit Erlangga, Jakarta.

Horngren, Charles T., Walter T. Harrison Jr. 2007. Akuntansi. Edisi 7, Jilid 1. Penerbit Erlangga, Jakarta.

Hutahaean, Jeperson. 2014. Konsep Sistem Informasi. Edisi 1. Deepublish, Yogyakarta.

http://atiahandayani.blogspot.com/2012/04/kas-.html

Ikatan Akuntansi Indonesia. 2012. Standar Akuntansi Keuangan. Salemba Empat, Jakarta.

Ida Nuraida. 2008. Manajemen Administrasi Perkantoran. Kanisius, Yogyakarta.

Indra Bastian. 2006. Akuntansi Pendidikan. PT Gelora Aksara Pratama, Jakarta.

Johar Arifin dan Achmad Sumaryono. 2007. Buku Kerja Berbasis Komputer untuk Manajer Keuangan dan Akuntansi. PT Elex Media Komutindo, Jakarta.

Johar Arifin. 2009. Akuntansi Pajak. PT Elex Media Komutindo, Jakarta. 
Kieso, Donal E., Jerry J. Weygant, Terry D. Warfield. 2011. Intermediate Accounting IFRS Edition. Volume 1. John Wiley \& Sons, Hoboken.

Kusrini dan Andri Koniyo. 2007. Tuntunan Praktis Membangun Sistem Informasi Akuntansi dengan Visual Basic dan Microsoft SQL Server. Penerbit Andi, Yogyakarta.

Rama, Dasaratha V., Frederick L. Jones. 2008. Sistem Informasi Akuntansi. Edisi 18, Buku 1. Salemba Empat, Jakarta.

Rudianto, 2012. Pengantar Akuntansi Konsep \& Teknik Penyusunan Laporan Keuangan Adaptasi IFRS. Penerbit Erlangga, Jakarta.

Samiaji Sarosa. 2009. Sistem Informasi Akuntansi. Grasindo, Jakarta.

SEQUOIA Content Production dan Leviandi Adhie. 2010. Internal Auditor dengan Microsoft Excel 2007. PT Elex Media Komputindo, Jakarta.

Slamet Sugiri Sodikin. 2013. Akuntansi Pengantar 2 Berbasis SAK ETAP 2009. Edisi Keenam. UPP STIM YKPN, Yogyakarta

Waluyo. 2008. Akuntansi Pajak. Salemba Empat, Jakarta.

Wahlen, James M., Jefferson P. Jones and Donald P. Pagach. 2013. Intermediate Accounting: Reporting and Analysis, 2E. Cengage Learning, Boston.

Warren, Carl S., James M. Reeve, Philip E. Fess. 2008. Pengantar Akuntansi. Edisi 21, Buku 1. Salemba Empat, Jakarta.

Warren, Carl S., James M. Reeve, Jonathan E. Duchac, Novrys Suhardianto, Devi Sulistyo Kalanjati, Amir Abadi Jusuf, Chaerul D. Djakman. 2014. Pengantar Akuntansi Adaptasi Indonesia.Edisi 25. Salemba Empat, Jakarta.

Wilson, Valerie., Suellen Freeman, John Freeman. 2011. Accounting: A Practical Approach. 3rd Edition. Pearson Australia, French Forest NSW

Zulkifli Amsyah. 2005. Manajemen Sistem Informasi. Gramedia Pustaka Utama, Jakarta.

Hakim, L. and Ariffin, M., 2013. Analisis Besaran Dividen Terhadap Besaran Laba Perusahaan. Jurnal IImiah Manajemen Kesatuan, 1(1), pp.61-70.

Setiawan, D.N. and Roestiono, H., 2014. Pengaruh Rasio CAMEL terhadap Tingkat Kesehatan Di Bank Tabungan Negara Syariah.

Prabowo, A. and Munawar, A., 2012. EVALUASI PENGELOLAAN MODAL KERJA SEBAGAI SARANA UNTUK MENGUKUR EFEKTIVITAS PERUSAHAAN DALAM MENGHASILKAN LABA. Jurnal Online Mahasiswa-Manajemen, 1(2). 
Munawar, A., 2003. Penerapan Metode Peramalan Penjualan Sebagai Dasar Penetapan Rencana Produksi (Studi Kasus di PT Varia Industri Tirta). Jurnal IImiah Kesatuan, pp.1-2.

Rosita, S.I., 2012. Studi pembiayaan Mudharabah dan Laba Perusahaan pada PT Bank Muamalat Indonesia TBK. Cabang Bogor". Jurnal Ilmiah Kesatuan, Nomor, 1.

Fadillah, A., 2012. Biaya Saluran Distribusi Melalui Kanvas Dan Pengaruhnya Terhadap Volume Penjualan. Jurnal IImiah Kesatuan (JIK), 14(1).

Sulistiono, S., 2012. PENGARUH PERSEPSI BUNDLING PRICING SEBAGAI PENUNJANG KEPUTUSAN PEMBELIAN DALAM SUDUT STATUS SOSIAL CUSTOMER (STUDI KASUS PADA PT. FORMEBASIC). In 2012 marketing symposium, 1 (1).

Rusmiyati, R. and Sumantri, S. 2014. TINJAUAN PEMBERIAN PEMBIAYAAN DENGAN JAMINAN Studi Kasus pada PT. Bank Syariah Mandiri Kantor Cabang Pembantu Tajur. Jurnal Online Mahasiswa-Manajemen, 1(2).

Oktaviani, I. and Suharmiati, S., 2013.PROSEDUR PEMBERIAN KREDIT MULTI GUNA (KMG) TERHADAP GOLONGAN PENGHASILAN TETAP Studi kasus pada PT. Bank Rakyat Indonesia (Persero) Tbk. Cabang Bogor Dewi Sartika. Jurnal Online Mahasiswa-Manajemen, 1(2). 